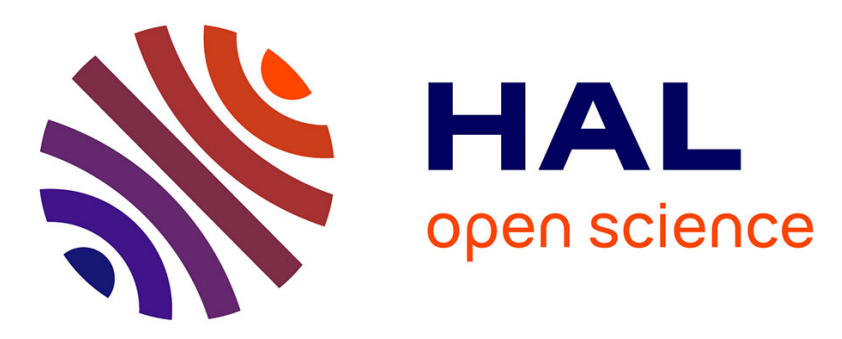

\title{
Simulation of block-and-ash flows and ash-cloud surges of the 2010 eruption of Merapi volcano with a two-layer model
}

Karim Kelfoun, Valentin Gueugneau, Jean-Christophe Komorowski, Naning Aisyah, Noer Cholik, Charley Merciecca

\section{To cite this version:}

Karim Kelfoun, Valentin Gueugneau, Jean-Christophe Komorowski, Naning Aisyah, Noer Cholik, et al.. Simulation of block-and-ash flows and ash-cloud surges of the 2010 eruption of Merapi volcano with a two-layer model. Journal of Geophysical Research : Solid Earth, 2017, 122 (6), pp.4277 - 4292. 10.1002/2017JB013981 . hal-01624998

\section{HAL Id: hal-01624998 \\ https://hal.uca.fr/hal-01624998}

Submitted on 20 Dec 2018

HAL is a multi-disciplinary open access archive for the deposit and dissemination of scientific research documents, whether they are published or not. The documents may come from teaching and research institutions in France or abroad, or from public or private research centers.
L'archive ouverte pluridisciplinaire HAL, est destinée au dépôt et à la diffusion de documents scientifiques de niveau recherche, publiés ou non, émanant des établissements d'enseignement et de recherche français ou étrangers, des laboratoires publics ou privés. 


\title{
Simulation of block-and-ash flows and ash-cloud surges of the
}

\section{0 eruption of Merapi volcano with a two-layer model.}

Karim Kelfoun ${ }^{1}$, Valentin Gueugneau ${ }^{1}$, Jean-Christophe Komorowski ${ }^{2}$, Naning Aisyah $^{3}$, Noer Cholik $^{3}$, Charley Merciecca ${ }^{1}$

1. Université Clermont Auvergne, CNRS, IRD, OPGC, Laboratoire Magmas et Volcans, F-63000 Clermont-Ferrand, France.

2. IPGP (Institut de Physique du Globe de Paris, Sorbonne Paris Cité, Université Paris Diderot, UMR 7154 CNRS), 1, rue Jussieu, 75238 Paris cedex 05, France.

3. BPPTKG (Balai Penyelidikan dan Pengembangan Teknologi Kegunungapian), Jl. Cendana no. 15 Yogyakarta - 55166, Indonesia.

\begin{abstract}
A new depth-averaged model has been developed for the simulation of both concentrated and dilute pyroclastic currents and their interactions [Kelfoun, submitted]. The capability of the model to reproduce a real event is tested for the first time with two well-studied eruptive phases of the 2010 eruption of Merapi volcano (Indonesia). We show that the model is able to reproduce quite accurately the dynamics of the currents and the characteristics of the deposits: thickness, extent, volume, and trajectory. The model needs to be tested on other well studied eruptions and the equations could be refined, but this new approach is a promising tool for the understanding of pyroclastic currents and for a better prediction of volcanic hazards.
\end{abstract}




\section{Introduction}

A pyroclastic density current (PDC in the following) is formed by hot rock fragments and gases, whose concentration varies in space and time, changing the current density. Even if transitions occur, two parts are commonly identified in the same current. Pyroclastic surges, also called dilute currents or dilute pyroclastic density currents (dilute PDCs) in the following, are high velocity and low-particle-concentration turbulent currents [e.g. Wright et al., 1980]. They are generally several tens of meters thick and leave relatively thin deposits [Fisher and Waters, 1970; Wohletz and Sheridan, 1979; Walker, 1984]. Their particles are generally small in diameter $(<1 \mathrm{~mm})$, although coarser elements are often found. They may originate from eruption column collapse, lava dome collapse or concentrated pyroclastic flows [Hoblitt et al., 1981; Waitt, 1981; Valentine, 1987]. Concentrated pyroclastic flows (called concentrated PDCs or simply flow in the following) are defined as high concentration currents whose thickness approaches that of their deposits [Fisher, 1979]. They are formed of a large range in particle sizes and can carry ash as well as cubic-meter-sized blocks. Concentrated and dilute PDCs are particularly devastating for humans and infrastructures. Due to their high mobility and their capacity to escape from channels, pyroclastic surges generally detach from the dense basal part, affect larger areas and are very dangerous for inhabitants in the vicinity of volcanoes. The physics of PDCs and of their interactions is still challenging. Numerical models can be used to explore the validity of physical laws and to determine the main parameters that influence PDC emplacement. There is also a strong need for the development of a robust numerical model for hazard assessment.

A new numerical model that simulates both the concentrated and the dilute parts of PDCs, and their interactions, is developed and explored theoretically in the companion paper [Kelfoun, submitted]. The model is compared here with a natural field case to check its ability to reproduce the natural phenomenon. For an objective estimation of the model's quality, it is 
necessary to reduce the number of free parameters in the model and to compare the maximum number of common features between the model and reality. We thus need an eruption with the maximum amount of detailed and quantified field data.

The 2010 eruption of Merapi volcano (Central Java, Indonesia) was one of the most destructive in the last century. It generated more than 100 pyroclastic currents, with a large range of volumes, energy and destruction [Cronin et al., 2013]. The activity was well monitored and observed, and the chronology of the events can be reconstructed [e.g. Jousset et al. 2013a; Surono et al., 2012; Budi-Santoso et al., 2013, Aisyah et al., 2010]. The deposits and the current characteristics (damage, directions, temperatures, etc.) have been studied in depth [Komorowski et al., 2013; Charbonnier et al., 2013; Cronin et al., 2013, Jenkins et al., 2013]. The complex topography of the area, with valley bends, valley depth variations and hills (Fig. 1a) make it possible to verify whether the velocities and thicknesses predicted by the model are correct or not. Moreover, several types of PDCs have been identified: valley-confined concentrated PDCs, overbank PDC lobes, high-energy dilute PDCs, dilute PDCs detached from the flows and surgederived pyroclastic flows formed by the dilute currents [Komorowski et al., 2013]. Finally, a high-resolution DEM (70 cm) has been calculated from a Lidar campaign carried out in 2012, after the eruption studied. Given that pyroclastic currents are very sensitive to meter-scale topography, a recent and accurate DEM is essential for correct modeling.

\section{The 2010 eruption of Merapi volcano}

The 2010 eruption of Merapi volcano has been extensively studied [e.g. Pallister et al., 2013; Surono et al., 2012; Komorowski et al., 2013, Charbonnier et al., 2013; Cronin et al., 2013, Jenkins et al., 2013]. 
Surono et al. [2012] and Jousset et al. [2013a] describe the chronology of the eruption and the succession of eruptive phases. Pallister et al. [2013] give a detailed description of the eruption chronology and estimate the extrusion rates. Budi-Santoso et al. [2013], Luehr et al. [2013] and Jousset et al. [2013b] present the 2010 eruption from several geophysical points of view, and Drignon et al., [2016] based on textural analyses and glass water content. Cronin et al. [2013], Charbonnier and Gertisser [2012], Komorowski et al. [2013], Jenkins et al. [2013] provide a chronology of the eruption and, map and describe the deposits. Charbonnier et al. [2013] map the different phases of the PDCs, detailing the concentrated flow deposits and combining field observations with satellite images. Komorowski et al. [2013] give a detailed examination of the distribution, stratigraphy and sedimentology of PDC deposits and a reconstruction of the properties of the dilute PDCs. Jenkins et al. [2013] focus on the impact of a major explosive eruption on a densely populated area and calculate the dynamic pressure and temperature of the dilute PDCs. The reader can refer to these works for additional information. Other aspects of the eruption are also discussed in a Special Volume dedicated to the 2010 eruption of Merapi [Jousset et al., 2013a]. The following summary is based on these previous studies.

\subsection{Chronology of the 2010 eruption}

The chronology of the eruption is known precisely thanks to the geophysical monitoring of the Merapi observatory, as well as first-hand accounts and field observations. Moreover, despite clouds that covered the volcano during much of the eruptive episodes, near real time monitoring of the volcanic activity and mapping of the extent of the PDCs were carried out using geophysical data and radar imagery [Pallister et al., 2013; Charbonnier et al., 2013; Komorowski et al., 2013; Solikhin et al., 2015].

After two months of enhanced levels of all monitored parameters (seismicity, ground deformation, etc. [Aisyah et al., 2010]) the first eruptive phase began on 26 October at 17:02, 
local time $(\mathrm{UT}+7)$. A laterally-directed phreatomagmatic explosion from a shallow magma intrusion or small cryptodome produced a crater $200 \mathrm{~m}$ wide and $100 \mathrm{~m}$ deep. This explosion destroyed the old summit dome complex and the shallow magma intrusion, but also evacuated the conduit filled with volatile-rich magma over several kilometers [Drignon et al., 2016]. It generated PDCs (dense and dilute) that traveled up to $5.4 \mathrm{~km}$ along the Opak valley and $6.8 \mathrm{~km}$ along the Gendol valley (locations on Fig. 1a). Eruptions and collapses of the old summit continued between 26 and 29 October, producing an estimated volume of $\sim 6 \times 10^{6} \mathrm{~m}^{3}$ [Surono et al., 2012].

After a short period of relative calm, a lava dome appeared on 29 October, as evidenced by incandescence. On 1 November several PDCs reached a distance of $9 \mathrm{~km}$ on the southern flank. Satellite radar imagery revealed that the dome growth during the period 1-4 November was extremely rapid for Merapi: the average rate for this period was $25 \mathrm{~m}^{3} \mathrm{~s}^{-1}$ [Surono et al., 2012], two orders-of-magnitude greater than during recent dome-building eruptions [Hammer et al., 2000]. This high extrusion rate was associated with several explosions notably on 30 and 31 October, 1 and 2 November, and with an $8 \mathrm{~km}$ high ash and gas plume [Surono et al., 2012; Pallister et al., 2013]. On 3 November, a series of magmatic explosions, associated with the concomitant growth and destruction of the lava dome that breached the southern part of the summit crater, generated PDCs $12 \mathrm{~km}$ in length. On 4 November, the new summit lava dome had been rebuilt to a volume of $\sim 5 \times 10^{6} \mathrm{~m}^{3}$. Recurrent explosions during this period of dome growth with a very high eruption rate produced a series of PDCs whose dilute part generated a succession of thin wavy-bedded sandy surge units [Jenkins et al., 2013].

The activity peaked on 5 November after 00:02 local time with a series of dome explosions and retrogressive collapses that destroyed the new dome (stage 4 of Komorowski et al. [2013]). The PDCs generated reached a distance of $16 \mathrm{~km}$ on the south flank and destroyed an area of about $22 \mathrm{~km}^{2}$ (Fig. 1c). At 00:13, another eruptive phase caused the retrogressive collapse of a large 
part of the summit (stage 5 of Komorowski et al. [2013]). This was followed by a subplinian phase (stage 6 of Komorowski et al. [2013]) between 02:11 and 04:21 local time that produced a convective plume that rose to more than $15 \mathrm{~km}$ in height and produced scattered pumice showers and thin mobile pumiceous PDCs channelized in the Gendol valley. Post-eruption images of the summit show a new, roughly circular crater with a diameter of $\sim 400 \mathrm{~m}$, breached to the southeast.

From 5 to 8 November, the activity changed to an intense degassing, with numerous mediumsized PDCs from explosions and collapses of the new lava dome which had formed after the peak activity. After 8 November, seismic activity gradually started to decrease in intensity. Satellite data indicated that dome growth ceased by 8 November following a brief 12 hour-long pulse at a remarkable rate of ca. $35 \mathrm{~m}^{3} \mathrm{~s}^{-1}$ [Surono et al., 2012].

We chose the 26 October and the 5 November eruptive phases to check the model validity because they have been well mapped and studied. They are described in more detail in the following sections.

\subsection{The 26 October pyroclastic currents}

The 26 October PDCs were generated by vulcanian explosions. Strong incandescence was also observed at the summit [Cronin et al., 2013]. The material included weathered and altered fragments, which probably derived from the old summit dome complex [Surono et al., 2012]. Drignon et al. [2016] recently provided evidence that this initial stage of the eruption was magmatic: the conduit was plugged by the summit's old dome complex and filled with volatilerich magma. PDCs moved southward up to a distance of $7.5 \mathrm{~km}$, following the Gendol valley that curves along the northwest side of the Kendil ridge (Fig. 1). The concentrated part formed massive blocks, lapilli and ash deposits of up to $15 \mathrm{~m}$ in thickness [Charbonnier et al., 2013]. 
The volume of those deposits has been estimated at about $2 \times 10^{6} \mathrm{~m}^{3}$, and their surface area at about $1 \mathrm{~km}^{2}$ (see Tab. 2 of Cronin et al. [2013]). The dilute part was unconfined and flowed across a $4 \mathrm{~km}^{2}$ area with a volume of about $0.21 \times 10^{6} \mathrm{~m}^{3}$, locally reaching thicknesses of $20 \mathrm{~cm}$ [Cronin et al., 2013]. Where measured, the mean particle diameter of the surge deposit was about $1 \phi(0.5 \mathrm{~mm}$ in diameter $)$ with a sorting of about $1.5 \phi$ [Charbonnier et al., 2013]. The mapping of the affected area varies slightly between Cronin et al. [2013] and Charbonnier et al. [2013] (Fig. 1b). According to seismic recordings, the duration of the PDC emplacements ranged from 2 to 33 minutes (see Tab. 1 of Cronin et al., 2013). The values of the parameters of the 26 October eruption, which are used in the model, are listed in Tab. 1.

\section{The 5 November pyroclastic currents}

The 5 November phase corresponds to the paroxysmal activity of the 2010 eruption. It corresponds to phase 3 of Charbonnier et al. [2013], the end of phase 3 of Cronin et al. [2013], to phase 4 of Komorowski et al. [2013], and this period is included in the magmatic phase (1-7 November) of Surono et al. [2012].

Dilute and concentrated currents were generated simultaneously by a series of dome explosions and retrogressive collapses that destroyed the new dome, from 00:02 to 00:13 local time. During these 11 minutes of paroxysmal activity, five distinct explosions were detected by seismic recorders [Komorowski et al., 2013]. Although each explosion most likely triggered partial dome collapse and emplacement of pyroclastic currents, only three distinct deposits have been identified [Komorowski et al., 2013]. The largest two explosions and associated partial dome collapses generated PDCs that were funneled through the Gendol Breach (Fig. 1). The transverse $240 \mathrm{~m}$ high Kendil ridge (Fig. 1) caused the surge to split and overpass the ridge to 
enter the Woro river drainage system to the southeast, while another part of the surge and the concentrated flow turned $90^{\circ}$ to the west to follow the upper Gendol valley.

In the sector of Kaliadem, at $4 \mathrm{~km}$ from the summit (Fig. 1), a large overflow caused the pyroclastic flows to enter the Opak valley while the main part turned $90^{\circ}$ south, following the Gendol valley where it was strongly channeled downstream and reached a distance of $15.5 \mathrm{~km}$ [Charbonnier et al., 2013]. Except close to Kaliadem, overflowing of the concentrated part was relatively limited. The overflowing, observed at numerous places along the Gendol valley (Fig. 1c, south of $y=9160 \mathrm{~km}$ ), which forms overbank lobes on the interfluves and relatively short channelized flows $(<1 \mathrm{~km})$ in neighboring drainage basins [Charbonnier et al., 2013, Thouret et al., 2015] was formed later, during the retrogressive collapse of the old summit (between 0:13 and 01:57, phase 5 of Komorowski et al. [2013]). The flow deposits of the 00:02-00:13 phase are composed of massive blocks, lapilli and ash of fresh, glassy, dense, dark-grey andesite. The median particle size is coarse and can reach $-6 \phi(64 \mathrm{~mm})$, and blocks of several cubic meters are frequent [Charbonnier et al., 2013]. The thickness of the concentrated flow deposit can reach $17 \mathrm{~m}$ locally [Charbonnier et al., 2013].

The surges destroyed an area of $22 \mathrm{~km}^{2}$, much larger than the flows. They escaped from the valleys where the flows are channelized, overflowing higher relief, among them the 240-mhigh of Kendil ridge, and blew down stretches of forest. On interfluves and ridge tops the dilute current formed characteristic thin, sandy, wave-bedded to massive, erosive surge deposits that locally have depositional and impact features typical of high-energy blast-like currents [Komorowski et al., 2013; Jenkins et al., 2013]. Interaction of the surges with the topography was complex and generated several lobes advancing simultaneously along subparallel drainage systems. The surge deposits show a trilobate distribution with a prominent lobe centered on the Gendol valley and secondary lobes centered on the Opak and Kuning valleys (Fig. 1c). Studies of surge deposits show three main units of turbulent currents (see the description of units U0, 
U1 and U2, and their subunits in Komorowski et al. [2013]), a blast component being suspected for some units. The deposit units reach up to $1.5 \mathrm{~m}$ and clast diameters are up to $20 \mathrm{~cm}$ close to the concentrated flows. The median diameter of the deposits varies from -4 to $4 \phi(16 \mathrm{~mm}-$ $0.06 \mathrm{~mm})$ with a mean median of about $2 \phi(0.25 \mathrm{~mm})$ (see Fig. 13 of Komorowski et al. [2013]). Clast densities associated with the paroxysmal phase vary from $2100 \mathrm{~kg} \mathrm{~m}^{-3}$ to $2700 \mathrm{~kg} \mathrm{~m}^{-3}$ with a mean of $2400 \mathrm{~kg} \mathrm{~m}^{-3}$ (see Fig. 15 of Komorowski et al., 2013). The volume of surge deposits has been estimated at $1.8 \times 10^{6} \mathrm{~m}^{3}$ [Cronin et al., 2013], $3.2 \times 10^{6} \mathrm{~m}^{3}$ [Charbonnier et al., 2013] and $3.52 \times 10^{6} \mathrm{~m}^{3}$ [Komorowski et al., 2013]. The temperature of the surge has been estimated to be less than $320^{\circ} \mathrm{C}$ [Jenkins et al., 2013; Trolese et al., 2016; Baxter et al., 2017]. This is compatible with the value obtained by Voight and Davis [2000] for the 1994 eruption of Merapi $\left(\mathrm{T} \sim 200-300^{\circ} \mathrm{C}\right)$ and by Charbonnier and Gertisser [2008] for the 2006 eruption $\left(\mathrm{T}>165^{\circ} \mathrm{C}\right)$. The temperature can differ between the hot particles and the gas of the dilute PDC. It is noteworthy that, according to the survivors of the 1994 eruption who were injured by the surge at its margin (northwest of Kaliurang town), the particles were burning while the gas was breathable (unpublished data gathered during the field work of Kelfoun et al. [2000]).

Deposits of valley-confined block-poor flows have also been formed during the paroxysmal phase. Komorowski et al. [2013] interpret these PDC deposits as high-concentration granular flows produced by rapid sedimentation from the dilute PDCs. Similar units, also called surgederived pyroclastic flows, were described at Soufrière Hills, Montserrat [Calder et al., 1999; Druitt et al., 2002] and Mount St. Helens [Fisher et al., 1987]. The volume of PDCs (flows and surges) deposits formed during the paroxysmal activity (00:02 to 00:13) is about $6 \mathrm{Mm}^{3}$. The total volume of the deposits formed between 00:02 and 01:57 is about $20 \mathrm{Mm}^{3}$. 


\section{Topography}

The Digital Elevation Model (DEM) used for the simulations was calculated following an aerial Lidar campain in 2012. The resolution is $70 \mathrm{~cm}$ and the data cover all the south flank of the volcano. Some areas of the volcano were covered by clouds and were not measured. The missing data were completed using oversampled data coming from a 15-m resolution DEM calculated by the Darmstadt University of Technology using photographs taken between 19811982 [Läufer, 2003; Gerstenecker et al., 2005]. This topography correction concerns the hills whose topography has not changed since 1981. The resolution of the DEM used in the simulations shown is $10 \mathrm{~m}$. With such a resolution, valleys and tributaries are visible on the DEM used and the calculation time of some hours on a desktop computer is compatible with an estimation of the best-fit parameters by trials and errors. Since the DEM was acquired in 2012, that is to say after the eruption, the topography is not exactly what it was during the current emplacement. The valleys were filled and then eroded but this essentially modify the valley bed and not changed drastically the surroundings that control the currents emplacement.

\section{The two-layer model}

Details and analysis of our two-layer model are described in Kelfoun [submitted]. The following sections summarize the main characteristics of the model.

\subsection{Governing equations}

PDCs are considered to be formed of two distinct parts: a concentrated part (here a block-andash flow) and a dilute part (the ash-cloud surge). Each part is simulated by a depth-averaged approach. For more details on the depth-averaged approach and on its limitations on complex topographies, and for references on recent advances, the reader may report to the companion 
article [Kelfoun, submitted]. The concentrated flow is simulated by solving three governing equations: mass and momentum equations in $x$ and $y$. Because the dilute current can be affected by strong density variation, a fourth equation is added in the system. Surges are thus simulated by four balance equations: gas mass, bulk mass and momentum in $x$ and $y$.

\subsection{Constitutive equations}

According to the results of previous simulations of pyroclastic flows, the physical behavior of the concentrated part (deposit and concentrated pyroclastic flows) is approximated by a predominantly plastic rheology with an additional term related to the square of the velocity $u$ which can take into account particle collisions or rock dismantling [Kelfoun et al., 2009; Charbonnier and Gertisser, 2012]. This rheology allows the formation of deposits of realistic thickness, extension and velocity with levee morphologies [Kelfoun, 2011]. The resistive stress T of a plastic flow is given by:

$$
\mathbf{T}=-T_{0} \frac{\mathbf{u}}{\|\mathbf{u}\|}-a_{1} \rho_{d}\|\mathbf{u}\| \mathbf{u}
$$

where $T_{0}$ is the yield strength, $\rho_{d}$ the concentrated flow density and $a_{1}$ a parameter that relates the velocity squared of the concentrated flow to the stress exerted. It has been estimated to be about 0.01 by Charbonnier and Gertisser [2012] and Charbonnier et al. [2013] for the concentrated PDCs of Merapi of 2006 and 2010, respectively. According to Eq. 1, below a given thickness that depends on $T_{0}$ and on the local slope, the mass is at rest. Above this critical thickness it begins to flow, forming a concentrated flow (primary or surge-derived).

Pyroclastic surges are considered to move in a predominantly turbulent mode [Wright et al., 1980] and their resistive stress is given by:

$$
\mathbf{R}=-a_{2} \rho_{s}\|\mathbf{v}\| \mathbf{v}
$$


where $a_{2}$ is a parameter that relates the turbulent stress to the velocity squared of the surge, $\rho_{s}$ is the surge density and $\mathbf{v}$ its velocity.

\subsection{Exchange laws}

The following laws describe the mass exchanges between the concentrated and the dilute currents. The particles of the flow can separate out to form the dilute current and, inversely, the dilute current can form either a basal concentrated flow or a deposit by sedimentation.

The mass flux of particles that leave the basal flow to the surge is considered to be a function of the velocity of the flow, based on experimental work on wind-blown sand [Xuan, 2004, and references therein]:

$$
\phi_{\mathrm{m}}=a_{3} \mathbf{u}^{3}
$$

The mass flux changes both the thickness and the density of the surge according to:

$$
\frac{d h_{s}}{d t}=\frac{\phi_{m}}{\rho_{m}}
$$

and

$$
\frac{d\left(\rho_{s} h_{s}\right)}{d t}=\phi_{m}
$$

where $\rho_{\mathrm{m}}$ is the density of the mixing that forms the dilute current.

The mass flux of particles leaving the surge by sedimentation to form either a flow or a deposit is expressed by:

$$
\phi_{\mathrm{s}}=\left(\rho_{\mathrm{s}}-\rho_{g}\right) w_{\mathrm{sed}}
$$


where $w_{\text {sed }}$ is the mean settling velocity of the particles [e.g. Sparks et al., 1997; Bonnadona et al., 1998]:

$$
w_{\text {sed }}=\sqrt{\frac{4\left(\rho_{p}-\rho_{s}\right) g d_{p}}{3 C_{d} \rho_{s}}}
$$

with $C_{\mathrm{d}}$ the drag coefficient and $d_{\mathrm{p}}$ the diameter of the particles.

Following Doyle et al. [2008; 2010], sedimentation is considered to affect the surge density but not its thickness. Where the density is locally lower than the atmosphere, the mass should lift off. This is taken into account in the model by removing the remaining mass of the surge from the system. Entrainment of the atmosphere is not taken into account in the model. The consequences of this assumption generally does not modify the dynamics of the current except where the surge density is low (i.e. close to its margin). The flows are assumed to be isothermal as documented by Trolese et al. [2016] and non-erosive, despite soil removal, rock striation and erosion of previous deposits of PDC being observed in the field.

\section{Input parameters of the model}

14 parameters must be defined for a simulation. Some parameters are known or can be estimated from field observations, at least within a given range (see Tab. 1). Five parameters are unknown and are estimated by a trial-and-error approach which compares numerical results to field data.

\subsection{Known parameters and estimated parameters}

Some parameters are known or can be estimated easily: topography, gravity or density of the atmosphere, for example.

Some parameters are fixed from a mean value of field measurements available (see section 2), for example the mean particle density, $\rho_{\mathrm{p}}$. Even if the parameters vary spatially, the variations 
are relatively small, and we therefore use constant values for the simulations. We chose the same values for both the 26 October and the 5 November phases.

The temperature of the 4 November surge deposit was estimated at $240-320^{\circ} \mathrm{C}$ and did not change significantly from proximal to distal areas [Trolese et al., 2016]. We thus assume that the temperature of the gas in the surge is also constant but is lower than that of the particles due to ingestion of air. With a mean temperature of $150^{\circ} \mathrm{C}$, the value of the gas in the surge is $\rho_{\mathrm{g}}=$ $0.645 \mathrm{~kg} \mathrm{~m}^{-3}$.

For the concentrated part (primary concentrated flows, surge-derived concentrated flows and deposits) the density is assumed to be $\rho_{\mathrm{d}}=1600 \mathrm{~kg} / \mathrm{m}^{3}$. It is the density of the ash fall measured by Komorowski et al. [2013] in the 2010 eruption deposits and is very close to the density of $1500 \mathrm{~kg} / \mathrm{m}^{3}$ used by Charbonnier et al. [2013] for the simulation of the concentrated part at Merapi. In fact, the exact value of the flow density is not critical: it acts on the dynamics through the ratio $T_{0} / \rho_{\mathrm{d}}$ and, as will be seen below, $T_{0}$ is estimated by a trial and error approach. The main consequence is that using a value for the density which is, for example, twice the real density will also lead to an estimation of the yield strength $T_{0}$ which is twice the correct value. We consider that the density of the concentrated flow is constant during emplacement and that its value is reached immediately on formation at the source.

The conditions of current genesis, at the vent, are determined with little accuracy. A retrogressive collapse has been described for the more voluminous currents. Laterally-directed explosions have also been described, but their influence on pyroclastic current emplacement is difficult to assess. Videos available of moderate explosions show that at least some PDCs are generated by vulcanian events: following the explosion, the mass falls into the crater and forms a concentrated flow that passes over the rim breach to the south. We base our vent conditions on this mechanism: whatever the exact genesis of PDCs, only concentrated pyroclastic flows 
are generated and they leave the crater at an initially low velocity by gravity alone. The resulting flows then generate a dilute current by displacement following Eq. 3.

For the two phases (26 Oct and 5 Nov), the source of PDCs is defined by a radius of $200 \mathrm{~m}$ in diameter located at the bottom of the crater (centered on $x=436465$ and $y=9166175$, UTM, WGS84). We simulate the retrogressive gravitational collapses or the vulcanian explosions by the release of a given volume at a constant rate, which is calculated by dividing the total volume of the event by the genesis duration (Tab. 1): numerically this is done by adding a given thickness of concentrated flow per second on the source area, with a null velocity, and by calculating the velocity of the covered mass by momentum conservation. Volumes and durations are known within a given range and their best values are estimated by fitting the simulation to the field data. For the 26 October phase, we simulate the longest unit of a series of pyroclastic currents [Cronin et al., 2013], whose total volume is about $2 \mathrm{Mm}^{3}$. The duration of the collapse is unknown but is shorter than the total duration of the current emplacement, which was between a few minutes and 30 minutes [Cronin et al., 2013]. For the 5 November phase, field data show that five units were emplaced during the 11 minutes of the paroxysmal activity, with a total volume of about $6 \times 10^{6} \mathrm{~m}^{3}$ [Komorowski et al., 2013]. We simulate the more voluminous and the more extensive PDCs that were generated during the peak activity, which lasted about $150 \mathrm{~s}$ according to geophysical data [Komorowski et al., 2013].

The mean particle diameter, $d_{\mathrm{p}}$, is considered to be $0.25 \mathrm{~mm}$ from field data, and is used for the two eruptions studied [Charbonnier et al., 2013; Cronin et al., 2013; Komorowski et al., 2013]. The coefficient $C_{\mathrm{d}}$ is a drag coefficient that rules the surge particle sedimentation and depends on the shape and roughness of particles, and on the flow dynamics. For a turbulent flow around one particle it is between 0.47 (smooth spheres) and 2 [Valentine, 1987; Woods and Bursik, 1991; Dellino et al., 2008; Dioguardi and Mele, 2015]. However, it becomes more complex with several particles in a turbulent mixture, and the $C_{d}$ value may be higher ( $\left.>10\right)$ [Bonnadona 
et al., 1998; Dioguardi and Mele, 2015]. The parameters $d_{\mathrm{p}}$ and $C_{\mathrm{d}}$ act on the settling velocity of the surge particles. We estimate the best settling velocity by fixing $d_{\mathrm{p}}$ and varying $C_{\mathrm{d}}$. within the estimated range (Tab. 1).

\subsection{Unknown parameters}

Five parameters are unknown and must be estimated by trial and error: the rheological parameters of the flow $\left(T_{0}, a_{1}\right)$ and of the surge $\left(a_{2}\right)$, the exchange coefficient $a_{3}$ from the flow to the surge, and the density $\rho_{\mathrm{m}}$ of the mixture formed by the fine particles of the flow with volcanic or atmospheric gases. $T_{0}$ can be estimated from the thickness of the flow deposit units or from the runout of the flow. The parameters $a_{1}$ can be estimated from the flow velocity and, indirectly, from the capability of the flow to cross a given relief. The parameter $a_{2}$ controls the surge velocity. It can be estimated by the more or less elongated shape of the area affected by the surges and by their capability to overflow reliefs, a low value of $a_{2}$ forming an elongated deposit downstream and overflowing the higher reliefs. The density of the mixing, $\rho_{\mathrm{m}}$, determines the surge thickness $h_{\mathrm{s}}$. A low value of $\rho_{\mathrm{m}}$ forms a thick, low density surge while a high value a thin, denser surge. However, the value of $\rho_{\mathrm{m}}$ has no influence on the mass of the surge and, consequently, it has little influence on the surge dynamics [Kelfoun, submitted], except where the surge thickness is close to the scale of the topographic relief. The value of $\rho_{\mathrm{m}}$ can be estimated by the elevation reached by the surge along the hills and by the capacity of the surge to flow out of the drainage basins and spread out on the interfluves. Finally, $a_{3}$ determines the mass flux from the flow to the surge and is estimated from the total mass of the surge deposits.

The order of magnitude of the best-fit parameters are then easily estimated before the simulation. The difficulty comes from the feedback effects. For example, let's imagine that the only parameter that does not fit is the runout of the concentrated flow, which is shorter in the 
simulation. If interactions with the surge were neglected, the value of $T_{0}$ just has to be lowered to adjust the model (a low value forms a long, thin flow). But, taking interactions into account, lowering this value will increase the concentrated flow velocity, and thus the mass flux that forms the surge and, consequently, the mass of the surge deposit. The mass lost by the flow will decrease its volume, which will decrease the flow runout, contrary to what was expected. $T_{0}$ and $a_{1}$, which control the concentrated flow velocity are the most sensitive parameters, the other parameters being associated with small feedback effects. The estimation of the most sensitive parameters requires more trial and errors simulations to converge towards the best result.

The sensibility of the results to the main parameters is illustrated in Tab. 2 and in the figures of the supplementary material. The maximal influence is caused by the parameters that control the fluxes from the flow to the surge and, consequently, those ruling the concentrated flow velocity: $a_{2}, a_{3}$ and the total volume involved.

\section{Results}

\subsection{Emplacement of the 5 November PDCs}

Fig. 2 shows the modelling of the 5 November PDCs whose parameters are listed in Tab. 1. A video of this modelling is added in the additional material. Due to the steep slope of the summit and to the relatively high mass rate, the concentrated flow accelerates rapidly to reach a velocity of $50 \mathrm{~m} / \mathrm{s}$. The high velocity leads to the strong genesis of a surge: the concentrated current loses mass (particles) at a rate of about $80 \mathrm{~kg} / \mathrm{m}^{2} / \mathrm{s}$, which corresponds to a loss of a $5 \mathrm{~cm}$-thick layer of the flow per second. Above the flow, the density of the dilute current rapidly reaches 8 $\mathrm{kg} / \mathrm{m}^{3}$, the maximum density imposed by the value of $\rho_{\mathrm{m}}$, and the thickness reaches about 100 m. The surge acquires its own momentum and, once it has left the flow, its density decreases laterally by sedimentation. 
To the north of the Kendil ridge, the flow curves to the southwest, following the Gendol drainage basin. The surge initially follows the same path but, because its thickness increases with time, it becomes thick enough to overflow the Kendil ridge (100 to $240 \mathrm{~m}$ high) and move southward. A part of the surge detaches from the flow and moves around the east flank of the Kendil ridge to enter the Woro valley (Fig. 2a and $2 \mathrm{~b}$ ). The surge that follows the Gendol valley becomes increasingly thicker because it is continuously being generated by the underlying concentrated part, which is channelized in the same valley.

At $t=150 \mathrm{~s}$, PDCs leave the Kendil ridge (location Fig. 1a) and reach an opened area where the Gendol valley is shallower (Fig. 2b). Due to its velocity and thickness, the concentrated part overflows the Gendol drainage basin to spread out on the interfluves. Part of the mass is channelized in the tributaries of the Opak valley and then flows along this valley for 3 kilometers. Because the surge is no longer channelized by the hilly topography, it can now spread out, covering a large arc-shaped sector from the Kuning valley in the west to the Woro valley in the east, and reaching $8 \mathrm{~km}$ from the summit to the south along the Opak and Gendol valleys (Fig. 1a and 2c). On this sector, the surge is generally thinner than $40 \mathrm{~m}$. New surges are still generated by the concentrated flows in the Opak and Gendol valleys but, because the slope is more gentle and because the concentrated flows spread out and thin, their velocities lower and surges are less energetic (Eq. 3) than those generated on the highest slopes of the volcano. Here, the velocities of the concentrated flows are between 10 and $20 \mathrm{~m} / \mathrm{s}$ (Fig. 2d) giving a mass flux $\phi_{\mathrm{m}}$ of less than $4 \mathrm{~kg} / \mathrm{m}^{2} / \mathrm{s}$ (i.e. loss of surface layer $<2 \mathrm{~mm}$ per second).

Once formed, the surges (i.e. the surge generated upstream and the later, less developed surges) progressively lose mass by sedimentation and their density decreases until they reach the density of the atmosphere. When atmospheric density is reached, the surge edges remain static while they are continuously supplied from the concentrated flow. When the supply decreases, the surges disappear progressively (by sedimentation and lift-off) from the supply areas to the 
outer edges (Fig. 2d). Fig. 3b shows the streamlines of the surges and indicates the direction of the trunks that would be blown down. They confirm that the main surge is formed upstream of the Kendil Ridge and expands radially once it has passed the ridge, and that, downstream, weaker surges are formed in the valleys but only affect their close surroundings.

At $500 \mathrm{~s}$, the concentrated flow, which is still moving, exits from the arc-shaped area covered by the main surge. It generates a current that is too dilute to spread out laterally over significant distances and that settles on the flow only.

The results described here are obtained with a total volume of $7 \times 10^{6} \mathrm{~m}^{3}$ (mass of $1.12 \times 10^{10} \mathrm{~kg}$ ) release during $150 \mathrm{~s}$. With such a volume and volume rate, some limited overflows of the valley's sides are sometimes observed up to some hundreds of meters (for higher volume, the mass flux makes the concentrated flow overflow all the valley's sides). The concentrated flow reaches runout distances of 6 and $15 \mathrm{~km}$ in the Opak and Gendol valleys respectively. The final deposit of the flow varies from $10-50 \mathrm{~cm}$ on the steep slopes of the cone to $5 \mathrm{~m}$ close to the front.

Surge isopachs (Fig. 3a) show four deposit lobes due to the influence of the main drainage basins (Kuning, Opak, Gendol and Woro) on the surge. The total volume deposited by the surges is $2.6 \times 10^{6} \mathrm{~m}^{3}$ and their maximal thickness reaches $30 \mathrm{~cm}$ close to the concentrated flow in the Gendol valley. The surge deposits are thinner on the higher relief and thicker at the bottom of the valleys. Locally, where the deposit is thick enough and the slope steep enough, the mass remobilizes after deposition, forming surge-derived concentrated flows that are able to flow for some hundreds of meters and that stop on gentler slopes (Fig. 3). With the parameters used (Tab. 1), surge-derived flows are formed where $h \sin \alpha>T_{0} /\left(\rho_{\mathrm{d}} g\right) \sim 16 \mathrm{~cm}$. This gives the minimal thickness to flow at $\sim 90 \mathrm{~cm}$ on a $10^{\circ}$-slope and $\sim 25 \mathrm{~cm}$ on a $40^{\circ}$-slope. 
Fig. $3 \mathrm{~b}$ also shows the dynamic pressure calculated by the model by $P_{\mathrm{dyn}}=\frac{1}{2} \rho_{s} \times\|\mathbf{v}\|^{2}$. The curves of equal pressure are more or less parallel to the isopachs. The dynamic pressure can be higher than $5 \mathrm{kPa}$ on the cone. Downstream, it is of about $1 \mathrm{kPa}$ in the inhabited areas of Kaliadem and Kalitengah (Fig. 2).

\section{2. $\quad$ Emplacement of the 26 October PDCs}

Fig. 4 shows the deposits of the 26 October pyroclastic currents. The currents are shorter than for the 5 November eruption but they share a similar behavior: flow velocities are high on the steep slopes and generate a relatively dense, thick surge; the dense flow is channelized in the Gendol drainage basin; and the relief of the Kendil influences the surge in a similar manner.

A good correspondence between the model and the reality is obtained for the parameters listed in Tab. 1. The main difference between the 26 October and the 5 November eruption, in the field, is the magnitude of the event. The concentrated flow follows the Gendol valley and, due to its small volume, it forms small overbanks but does not overflow into the Opak valley. The dilute current forms two lobes. The first lobe detaches from the flow of the Gendol valley, where it curves to the southwest, and overflows the Kendil ridge. It reaches the Woro drainage basin, where it moves for $1.5 \mathrm{~km}$. The other lobe spreads out on the flatter area downstream of the Kendil ridge. This lobe spreads out laterally over $700 \mathrm{~m}$ to the east of the Gendol valley and over $1000 \mathrm{~m}$ to the west. Surge deposit thickness is maximal at $10 \mathrm{~cm}$ close to the flow. The maximum velocity of the concentrated flow is $40 \mathrm{~m} / \mathrm{s}$ on the steepest slopes of the cone and it decreases at less than $20 \mathrm{~m} / \mathrm{s}$ downstream of Kaliadem (Fig. 2). The surge reaches $60 \mathrm{~m} / \mathrm{s}$ north of Kendil ridge and then moves at a mean velocity of about $25 \mathrm{~m} / \mathrm{s}$ in both the Woro and the Gendol areas. It is faster than the flow that is thin enough to slowed down by its yield strength 
$T_{0}$. However, the surge stops at about $6 \mathrm{~km}$ from the summit by lift-off while the concentrated part continues to flow, overtakes the surge bourdary and finally stops at $7 \mathrm{~km}$ from the summit.

\section{Discussion}

A comparison between the simulations (Fig. 3-4) and the field data (Fig. 1) shows a good correspondence both for the 26 October and the 5 November eruptive phases.

For the 26 October eruption, the simulated concentrated flow reproduces the runout, the extent and the thickness of the natural phenomena (Fig. 1b and 4). The velocity of an actual flow has not been observed but the channelizing in the Gendol valley and the extent of the concentrated deposits indicate that the velocity of the simulation is very close to reality. The surge velocity on the terminal cone is $60 \mathrm{~m} / \mathrm{s}$ in the model, which corresponds to velocities deduced from videos of similar phases. As in the field, the surge detaches from the Gendol drainage basin to flow in the Woro drainage basin. Another surge spreads out on the interfluves of the Gendol valley. To the west, the model fits with field data while, to the east, the lateral extent reached by the surge in the model is greater than in reality ( $700 \mathrm{~m}$ and $200 \mathrm{~m}$ respectively). The thickness of dilute current deposits is close to the real deposits.

For the 5 November eruption, the flow deposit also shows similar characteristics: the overall shape of the area covered by the concentrated flow, the overflow into the Opak valley to the south of Kendil ridge and the runout in the Gendol and the Opak valleys. The large overbanks mapped in the southern part of the Gendol valley are not reproduced but they were formed during another eruptive phase, which is not simulated here (stage 5, Komorowski et al., 2013). The thickness of one unit, nearly constant at $\sim 5 \mathrm{~m}$ from Kendil ridge to the front, is compatible with reality. For the surge, its density is close to the value estimated $\left(\sim 5 \mathrm{~kg} / \mathrm{m}^{3}\right.$, Jenkins et al., 2013) as well as its thickness. The overall shape of the surge deposits corresponds to the real deposits, with a similar thickness over the whole area, and the isopachs elongated southward to 
form lobes that follow the main drainage basins. The surge trajectories generally coincide with the directions of the blown-down trees [Komorowski et al., 2013]. The total volume of surge deposits $\left(2.6 \times 10^{6} \mathrm{~m}^{3}\right)$ fits with the field data.

All those points show that, at least to the first order, the physics chosen and the parameters of the model are close to these of the natural event. For the concentrated flow, a correct path means that both the thickness and the velocity are correctly calculated and, consequently, that the rheology chosen is realistic. The realistic thickness of the deposits indicates that the rheology is not only adapted for the simulation of the emplacement phase but also for the stopping phase. This conclusion was already drawn for the 2009 eruption of Tungurahua [Kelfoun et al., 2009] and for the 2006 eruption of Merapi [Charbonnier and Gertisser, 2012]. The present study, with a complex path composed of bends and overbanking, confirms the adequacy of the law and the magnitude of the values used for the simulation of the concentrated flow: $T_{0}=5 \mathrm{kPa}$, $a_{1}=0$ for Tungurahua, $3.5<T_{0}<7.5 \mathrm{kPa}, a_{1}=0.01$ for Merapi in 2006 and $T_{0}=2.5 \mathrm{kPa}, a_{1}=$ 0.01 in this study. It also seems that the depth-averaged approach is suited to the simulation of pyroclastic surges along most of their emplacement. Of course, the model uses 14 parameters, of which 5 (even 6 including the large range of $C_{\mathrm{d}}$ ) are adjustable by a trial and error approach. But the number of field data used for the comparison and, overall, the spatial distribution of the data over the entire damaged area are significantly greater than the number of free parameters. This gives confidence in the model results and in the values used.

However, in detail, some significant differences can be observed between the model and the natural deposits. Surge-derived concentrated flows are formed in the model by the sedimentation of the surge and then by remobilization. For the parameters used, they are less developed than the block-poor derived PDC described by Komorowski et al. [2013]. Results are closer to reality for thicker surge deposits or for lower values of $T_{0}$, but this causes a worse fit with other observations. The mean surge velocity seems correct but, locally, the velocity is 
underestimated compared to field data. For example, it is $35 \mathrm{~m} / \mathrm{s}$ where it has been measured at $47-52 \mathrm{~m} / \mathrm{s}$ from superelevation measurements [Fig. 16a of Komorowski et al., 2013] at the ridge separating the Gendol valley from the upper Opak valley. If the field estimation is correct, the lower value in the simulations might be explained by the presence of vortices that are not simulated and can locally increase the velocity of gas and particles. The dynamic pressure seems to be systematically underestimated by the model. For example, it has been simulated at about $1 \mathrm{kPa}$ in the Kaliadem sector, where it is measured as $15 \mathrm{kPa}$ in the field [Jenkins et al., 2013]. The discrepancy might be due to the depth-averaging. In the model, there is no vertical variation in density while in reality, density increases downward [e.g. Valentine, 1987]. The dynamic pressure in the field is related to the surge density and velocity at the ground. In our model, the dynamic pressure is calculated using both the mean density and the mean velocity of the surge. This would inevitably underestimate the density at the ground and, consequently, the dynamic pressure. This could be improved by assuming a density profile in the surge. A more complex genesis of surges, implying overpressure, might be another explanation of this too low dynamic pressure of the model.

The velocity of the concentrated flow front is very slow for several tens of minutes before it stops. This is due to the concentrated mass that converges from the Gendol tributaries and slowly accumulates downstream. Although it is difficult to observe, such a slow stopping phase has never been described. Remember that the rheology used for the concentrated part is adapted to the first order but that it lacks a physical basis and is probably not accurate in detail. This rheology does not explicitly take into account the rheological/mechanical transitions when the dome dismantles to form a flow and when the flow changes to a deposit. The presence of deposits, even very thin ones, on the steep terminal cone is not observed in the field and is another consequence of the first-order rheology used. 
Finally, some parameters seem to be high even though they do fall within the estimated range. The best total volume is high compared to the field estimation: $<2 \times 10^{6} \mathrm{~m}^{3}$ in the field and $2 \times 10^{6} \mathrm{~m}^{3}$ in the model on 26 October; $<6 \times 10^{6} \mathrm{~m}^{3}$ in the field and $7 \times 10^{6} \mathrm{~m}^{3}$ in the model for 5 November. This could be due to the lack of accuracy in the field measurements or to our assumption that the concentrated flow density equals that of the deposits. The entrainment of previous deposits, which is not simulated, may be another explanation [Bernard et al., 2014]. The DEM resolution of $10 \mathrm{~m}$ might smooth the details of the topography. Between two points of the DEM we assume that the elevation changes linearly even if the change is sharp (horizontal areas separated by vertical cliff, for example) in the field. Also remember that the DEM has been calculated after the eruption and that the valleys morphology was smoothed by the recent deposits. Thus, higher volumes are needed to obtain the same thickness and runout as in reality. To reproduce the extension and thickness of surge deposits, the settling velocity of the surge needs to be about $0.15 \mathrm{~m} / \mathrm{s}$ and $C_{\mathrm{d}}$ is about 30 . Even if possible, such a value of $C_{\mathrm{d}}$ is very high. It is possible that this high value hides other phenomena that would decrease the particle settling velocity and that are not considered in the model: a strong increase of the surge density downward, interactions between particles, or upward gas movements (e.g. thermal buoyancy, air ingestion and heating) in the surge that counteract particle fall, for example.

Observing the high intensity of damage of the 5 November eruption, we can speculate if the processes at the origin of the surges were different to those of the previous eruptions of Merapi (1994, 2006, 26 October 2010 for example). Our model cannot exclude that the destruction could have been caused by different mechanisms, such as a laterally-directed explosive component with a blast origin, but we show that a different mechanism is not needed to explain the characteristics of surge deposits of the 5 November eruptions. The extension of the damaged area can be explained by a surge, generated by a basal concentrated flow and moving as a density current. The power of the surge, compared to the eruptions of the last century at Merapi 
and to the previous phases of 2010 , is explained in the model by the large volume that flowed rapidly, generating a large mass flux from the concentrated to the dilute current. This would have generated a thick $(>100 \mathrm{~m})$ and dense $\left(8 \mathrm{~kg} / \mathrm{m}^{3}\right)$ surge, which was able to detach from the concentrated flow and move rapidly $(>20 \mathrm{~m} / \mathrm{s})$ up to large distances from the flow. The model shows that volume collapsed plays a large role in surge genesis but the volume rate is also very critical: a given volume collapsing in a short time period generates a more powerful surge than the same volume produced over a longer time. The model could then contribute to answer the question posed by Cronin et al. [2013]: "why are some phases associated with powerful surges while the majority of the concentrated flows in 2010 and all the currents in 2006 are associated with small dilute currents?". They envisaged several hypotheses and note that there is no relation with the volume of the flow, because a small volume flow was associated with a powerful surge (S1, 26 October, Cronin et al., 2013). Even if this does not exclude other mechanisms, our model shows that a small volume released in a short time period $(<30 \mathrm{~s})$ leads to a high volume rate and can generate a strong surge, a large mass of the concentrated flow being transferred to the dilute current.

What can be said about the values of $a_{2}, \rho_{\mathrm{m}}$ and $T_{0}$ that differ between the two eruptions? Are the differences related to physical parameters that would differ between the eruptions, such as the rock/lava temperature, the gas content, etc.? For example, a higher temperature might change the concentrated flow fluidity (lower $T_{0}$ ), the mixing density above the concentrated flow $\left(\rho_{\mathrm{m}}\right)$ or the surge retarding stress $\left(a_{2}\right)$ by increasing surge turbulence. There is a lack of field data to answer this question. A better understanding of the rheologies, of the physics of the phenomena and of the exchanges is fundamental to improve the model and to better estimate associated hazards. Among them, the exchange law between the concentrated and the dilute current is critical and is probably more complex that the law used here (Eq. 3). We stress out that, even if the dependence of the surge genesis to the flow velocity cubed seems to be a good 
approximation, as in the wind tunnel experiments, this does not prove that surge formation is related to saltation. There is a real need for theoretical and experimental work to understand the physics of exchanges and to relate the value of $a_{3}$ (or of other parameters in a more complex law) to the physical parameters of the two currents: temperature, velocity, particle size distribution, etc. To go further, we also need to develop and improve observation of real pyroclastic currents to reduce the uncertainties on the values used. Finally, the simulation of other well observed pyroclastic currents are needed to determine if the conclusions drawn for the two eruptions of Merapi in 2010 can be extrapolated to other volcanoes and if the model can be used as a predictive tool.

\section{Conclusion}

We have developed a new model for pyroclastic currents that couples the basal concentrated flow to the dilute part of the current. The model is based on two distinct depth-averaged currents, the density of the dilute current changing in time and space. We show that the model is able to reproduce quite accurately PDC emplacement from two phases of different intensity that occurred during the 2010 eruption of Merapi volcano.

The model will be tested with other well constrained eruptions and efforts must be made towards a better understanding of the physics of these currents and of the exchanges between the currents. Nevertheless, this new model gives promising perspectives for the understanding of pyroclastic current emplacements and for future estimation of related hazards and impacts on the population, the infrastructure, and the environment.

\section{Acknowledgment}

This work has be founded by the Domerapi - ANR (French Agence Nationale de la Recherche) Project (ANR-12-BS06-0012). This is the LabEx ClerVolc contribution $n^{\circ} 250$. The data for 
this paper are available by contacting the corresponding author at k.kelfoun@opgc.fr. We are very grateful to both Dr. Tomaso Esposti Ongaro and an anonymous reviewer for their constructive remarks. 


\section{References}

Aisyah, N., S. Sumarti, D. S. Sayudi, A. Budi-santoso, M. Muzani, S. Dwiyono, Sunarto, and Kurniadi (2010), Aktivitas G. Merapi Periode September-Desember 2010 (Erupsi G. Merapi 26 Oktober-7 November 2010). Bull. Berkala Merapi 07/03.

Baxter, P. J., Jenkins, S., Rosadi, S., Komorowski, J-C., Dunn, K., Purser, D., Voight, B., and Shelley' I. (2017) Human survival in volcanic eruptions: thermal injuries in pyroclastic surges, their causes, prognosis and emergency management, Burns, 2017 Feb 21. pii: S03054179(17)30044-X., doi: 10.1016/j.burns.2017.01.025.

Bernard, J., K. Kelfoun, J.L. Le Pennec, S., and Vallejo Vargas S. (2014), Pyroclastic flow erosion and bulking processes: comparing field-based vs. modeling results at Tungurahua volcano, Ecuador. Bulletin of Volcanology vol.76, p.858, doi:10.1007/s00445-014-0858-y.

Bonnadona, C., G. G. J. Ernst, and R. S. J. Sparks (1998), Thickness variations and volume estimates of tephra fall deposits: the importance of particle Reynolds number. J. Volcanol. Geotherm. Res., 81, 173-187.

Budi-Santoso, A., P. Lesage, S. Dwiyono, S. Sumarti, S. Subandriyo, Surono, P. Jousset, and J. P. Metaxian (2013), Analysis of the seismic activity associated with the 2010 eruption of Merapi Volcano, Java, J. Volcanol. Geotherm. Res., 261 (1), 153-170.

Calder, E. S., P. D. Cole, W. B. Dade, T. H. Druitt and R. Hoblitt (1999), Mobility of pyroclastic flows and surges at the Soufrie re Hills Volcano, Montserrat. Geophysical Research Letters, 26, 537-540, http://dx.doi.org/10.1029/1999GL900051

Charbonnier, S. J., and R. Gertisser (2008), Field observations and surface characteristics of pristine block-and-ash flow deposits from the 2006 eruption of Merapi Volcano, Java, Indonesia, J. Volcanol. Geotherm. Res., 177, 971-982.

Charbonnier, S. J., and R. Gertisser (2012), Evaluation of geophysical mass flow models using the 2006 block-and-ash flows of Merapi Volcano, Java, Indonesia: towards a shortterm hazard assessment tool, J. Volcanol. Geotherm. Res., 231-232, 87-108.

Charbonnier, S. J., A. M. Germa, C. B. Connor, R. Gertisser, K. Preece, J.-C. Komorowski, F. Lavigne, T. H. Dixon, and L. J. Connor (2013), Evaluation of the impact of the 2010 pyroclastic density currents at Merapi volcano from high-resolution satellite imagery, field investigations and numerical simulations, J. Volcanol. Geotherm. Res., 261, 295-315.

Cronin, S. J., G. Lube, D. S. Dayudi, S. Sumarti, S. Subrandiyo, and Surono (2013), Insights into the October-November 2010 Gunung Merapi eruption (Central Java, Indonesia) from the stratigraphy, volume and characteristics of its pyroclastic deposits, 261, 244-259.

Dellino, P., D. Mele, R. Sulpizio, L. La Volpe, and G. Braia (2008), A method for the calculation of the impact parameters of dilute pyroclastic density currents based on deposit particle characteristics, J. Geophys. Res., 113, B07206, doi:10.1029/2007JB005365.

Dioguardi, F, and D. Mele (2015), A new shape dependent drag correlation formula for nonspherical rough particles. Experiment and results. Powder Technology, 277, 222-230. 
Doyle, E. E., A. J. Hogg, H. M. Mader, and R. S. J. Sparks (2008), Modeling dense pyroclastic basal flows from collapsing columns. Geophysical Research Letters, 35, 1-5, http://dx.doi.org/10.1029/2007GL032585

Doyle E. E., A. J. Hogg, H. M. Mader, and R. S. J. Sparks (2010), A two-layer model for the evolution and propagation of dense and dilute regions of pyroclastic currents, J. Volcanol. Geotherm. Res., 190, 365-378.

Drignon, M., Bechon, T., Arbaret, L., Burgisser, A., Komorowski, J-C., Martel, C., Miller, H., Putra R. (2016). Pre-explosive conduit conditions during the 2010 eruption of Merapi volcano (Java, Indonesia). Geophysical Research Letters, 43, doi:2016GL071153

Druitt, T.H., E.S. Calder, P.D. Cole, R.P. Hoblitt, S.C. Loughlin, G.E. Norton, L.J. Ritchie, R.S.J. Sparks, and B. Voight (2002), Small-volume, highly mobile pyroclastic flows formed by rapid sedimentation from pyroclastic surges at Soufrière Hills Volcano, Montserrat: an important volcanic hazard. In: Druitt, T.H., Kokelaar, B.P. (Eds.), The Eruption of Soufriere Hills Volcano, Montserrat, from 1995 to 1999, 21. Geol. Soc. Mem. Geol. Soc. of London, London, pp. 263-279.

Gerstenecker, C., G. Läufer, D. Steineck, C. Tiede, and B. Wrobel (2005), Validation of Digital Elevation Models around Merapi Volcano, Java. Indonesia, Natural Hazards and Earth System Sciences, 5, 863-876.

Fisher, R. V., and A. C. Waters (1970), Amer. J. Sci., 268, 157.

Fisher R. V. (1979), Models for pyroclastic surges and pyroclastic flows, J. Volcanol Geotherm Res 6:305-318

Fisher, R.V., H.X. Glicken, and R.P. Hoblitt (1987), May 18, 1980, Mount St. Helens deposits in South Coldwater Creek, Washington. J. Geophys. Res., 92, 10267-10283.

Hammer, J. E., K.V. Cashman, and B. Voight (2000), Magmatic processes revealed by textural and compositional trends in Merapi dome lavas, J. Volcanol. Geotherm. Res., 100, 165-192.

Hoblitt, R. P., C. D. Miller, and J. W. Vallance (1981), Origin and stratigraphy of the deposit produced by the May 18 directed blast. In: Lipman, P.W., Mullineaux, D.R. (Eds.), The 1980 Eruptions of Mount St. Helens, Washington: US Geol Surv Prof Pap, 1250, pp. 401-419.

Jenkins, S., J.-C. Komorowski, P. Baxter, R. Spence, A. Picquout, F. Lavigne, and Surono (2013). The Merapi 2010 eruption: An interdisciplinary impact assessment methodology for studying pyroclastic density current dynamics, J. Volcanol. Geotherm. Res., 261 (1), 316-329.

Jousset, P., J. Pallister, J., and Surono (2013a), The 2010 eruption of Merapi volcano, J. Volcanol. Geotherm. Res., 261 (1), 1-6.

Jousset, P., A. Budi-Santoso, A. D. Jolly, M. Boichu, Surono, S. Dwiyono, A. Sumarti, S. Hidayati, and P. Thierry (2013b), Signs of magma ascent in LP and VLP seismic events and link to degassing: An example from the 2010 explosive eruption at Merapi volcano, Indonesia. Indonesia. Merapi eruption, J. Volcanol. Geotherm. Res., 261 (1), 171-192. 
Kelfoun K. (submitted), A two-layer depth-averaged model for both the dilute and the concentrated parts of pyroclastic currents, submitted to J. of Geophys. Res., January. 2017

Kelfoun, K., F. Legros, and A. Gourgaud (2000), A statistical study of trees damaged by the 22 November 1994 eruption of Merapi volcano (Java, Indonesia): relationships between ash-cloud surges and block-and-ash flows, J. Volcanol. Geotherm. Res., 100 (1-4), 379-393.

Kelfoun K., P. Samaniego, P. Palacios, and D. Barba (2009), Testing the suitability of frictional behaviour for pyroclastic flow simulation by comparison with a well-constrained eruption at Tungurahua volcano (Ecuador). Bull. Volcanol., 71(9), 1057-1075, DOI: 10.1007/s00445-0090286-6.

Kelfoun K. (2011), Suitability of simple rheological laws for the numerical simulation of dense pyroclastic flows and long-runout volcanic avalanches: J. Geophys. Res., Solid Earth, 116, B08209. doi:10.1029/2010JB007622.

Komorowski, J.-C., S. Jenkins, P. J. Baxter, A. Picquout, F. Lavigne, S. Charbonnier, R. Gertisser, K. Preece, N. Cholik., A. Budi-Santoso, and Surono (2013), Paroxysmal dome explosion during the Merapi 2010 eruption: Processes and facies relationships of associated high-energy pyroclastic density currents, J. Volcanol. Geotherm. Res., 261 (1), 260-294 Special Issue: Merapi eruption.

Läufer, G. (2003), Erzeugung hybrider digitaler Höhenmodelle aktiver Vulkane am Beispiel des Merapi, Indonesien, PhD thesis, Darmstadt University of Technology, Aachen.

Luehr, B. G., I. Koulakov, W. Rabbel, J. Zschau, A. Ratdomopurbo, K. S. Brotopuspito, P. Fauzi, and D. P. Sahara (2013), Fluid ascent and magma storage beneath Gunung Merapi revealed by multi-scale seismic imaging, J. Volcanol. Geotherm. Res., 261 (1), 7-19.

Pallister, J.S., D. J. Schneider, J. P. Griswold, R. H. Keeler, W. C. Burton, C. Noyles, C. G. Newhall, and A. Ratdomopurbo (2013), Merapi 2010 eruption-Chronology and extrusion rates monitored with satellite radar and used in eruption forecasting, J. Volcanol. Geotherm. Res., 261, 138-146.

Solikhin, A., Thouret, J-C., Liew S.C., Gupta, A., Sri Sayudi, D., Oehler, J-F., and Kassouk, Z. (2015) High-spatial-resolution imagery helps map deposits of the large (VEI 4) 2010 Merapi Volcano eruption and their impact. Bull Volcanol ; 77 :20 ; DOI 10.1007/s00445-015-0908-0

Sparks, R., M. Bursik, S. Carey, J. Gilbert, L. Glaze, H. Sigurdsson, and A. Woods (1997), Volcanic Plumes. Wiley, New Jersey.

Surono, P. Jousset, J. Pallister, M. Boichu, M. F. Buongiorno, A. Budi-Santoso, F. Costa, S. Andreastutti, F. Prata, D. Schneider, C. Lieven, H. Humaida, S. Sumarti, C. Bignami, J. Griswold, S. Carn, C. Oppenheimer, and F. Lavigne (2012), The 2010 explosive eruption of Java's Merapi volcano_a '100-year' even, J. Volcanol. Geotherm. Res., 241-242, 121-135.

Thouret J.C., Z. Kassouk, A. Gupta, S. C. Liew, and A. Solikhin (2015), Tracing the evolution of 2010 Merapi volcanic deposits (Indonesia) based on object-oriented classification and 
analysis of multi-temporal, very high resolution images. Remote Sens. Environ., 170, 350-371, doi:10.1016/j.rse.2015.09.028.

Trolese, M., Giordano, G., Komorowski, J-C., Jenkins, S., Baxter, P.J., Cholik, N., and Raditya, P. (2016) Thermal behavior of the high-energy PDCs associated with the 2010 Merapi éruption. Cities on Volcanoes COV9, "Understanding volcanoes and society: the key for risk mitigation", International Association of Volcanology and Chemistry of the Earth's Interior (IAVCEI), Puerto Varas, Chile, 20-125 November 2016, abstract

Valentine, G. A. (1987), Stratified flow in pyroclastic surges. Bull. Volcanol. 49, 616-630.

Voight, B., and M. J. Davis (2000), Emplacement temperatures of the November 22, 1994 nuée ardente deposits, Merapi Volcano, Java, J. Volcanol. Geotherm. Res., 100 (1-4), 371-377.

Waitt, R. B. J. (1981), Devastating pyroclastic density flow and attendant air fall of May 18 stratigraphy and sedimentology of deposits. In: Lipman, P.W., Mullineaux, D.R. (Eds.), The 1980 Eruptions of Mount St. Helens, Washington: US Geol Surv Prof Pap, 1250, pp. 439-458.

Walker, G. P. L. (1984), Characteristics of dune-bedded pyroclastic surge bedsets. J. Volcanol. Geoth. Res., 20, 281-296

Wohletz, K. H., and M. F. Sheridan (1979), A model of pyroclastic surge. Geol. Soc. Am. Spec. Pap. 180, 177-194.

Woods, A. W., Bursik M. I. (1991), Particle fallout, thermal disequilibrium and volcanic plumes. B Volcanol. 53, 559-570, doi: 10.1007/BF00298156

Wright, J. V., A. L. Smith, and S. Self (1980), A working terminology of pyroclastic deposits, J. Volcanol. Geotherm. Res., 8 (2-4), 315-336, http://dx.doi.org/10.1016/03770273(80)90111-0

Xuan J. (2004), Turbulence factors for threshold velocity and emission rate of atmospheric mineral dust. Atmospheric Environment 38(12): 1777-1783. 


\section{Caption}

Figure 1: (a) Locations used in the text. Rivers are in dashed lines. GB: Gendol breach, GF: Gendol funnel, Ka: sector of Kaliadem. (b - c) Deposits of surges and flows of Merapi formed by (b) the $26^{\text {th }}$ October 2010 and (c) the $5^{\text {th }}$ November 2010 eruption. The map of the $5^{\text {th }}$ November represent all the deposits and not only those of the paroxysmal phase simulated. Data come from Charbonnier et al., 2013; Cronin et al., 2013 and Komorowski et al., 2013. The differences in the mapping are shown on the figures.

Figure 2: emplacement of the concentrated and the dilute currents for the 5 November 2010 eruption of Merapi volcano at (a) $t=100 \mathrm{~s}$, (b) 200s, (c) $300 \mathrm{~s}$ and (d) $400 \mathrm{~s}$. Movie in supplementary material.

Figure 3: (a) Thickness of surge and concentrated flow deposits. Total surface of deposits 27.11 $\mathrm{km}^{2}$, surface of surge deposits: $22.14 \mathrm{~km}^{2}$, volume of surge deposits (excluding settling on the flow): $1.88 \times 10^{6} \mathrm{~m}^{3}$. (b) Maximal dynamic pressure and surge trajectories. The trajectories show the influence of relieves on surge emplacement. Eruption of the 5 November.

Figure 4: simulation of surge and concentrated flow deposits for the 26 October 2010 eruption of Merapi volcano.

Table 1: parameters used in the model. Known, estimated or calculated.

Table 2: sensibility of the simulations to the parameters variations. See the supplementary material for the figures of all the simulations listed here. Area $=$ total area covered by deposits (surge + flow) $\left(\mathrm{km}^{2}\right)$, Volume $=$ volume of surge deposits $\left(\times 10^{6} \mathrm{~m}^{3}\right)$, Runout $=$ maximal distance reached by the surge $(\mathrm{km})$, Width $=$ maximal surge width $(\mathrm{km}, \mathrm{E}-\mathrm{W}$ direction $)$, Area $\mathrm{SF}=$ area affected by secondary flows $\left(\mathrm{km}^{2}\right)$. The area covered by the surge-derived flow is very sensitive to all parameter changes. The volume of the surge deposit and the area covered by the surge are mostly sensitive to the parameters that control its genesis: $V, a_{2}$ and $a 3$. 


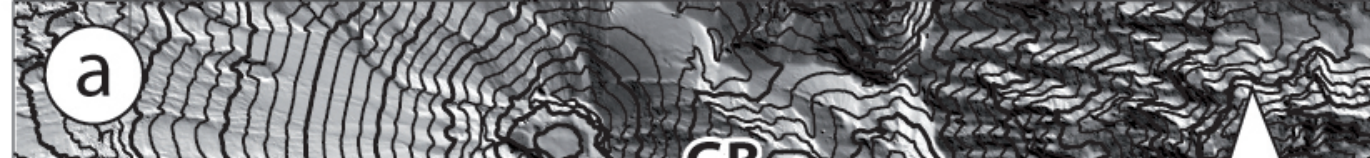
- (C)

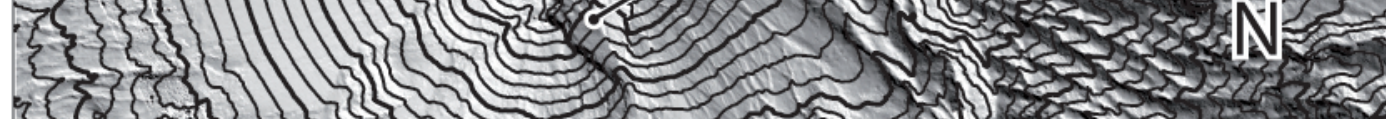
政\{ E2

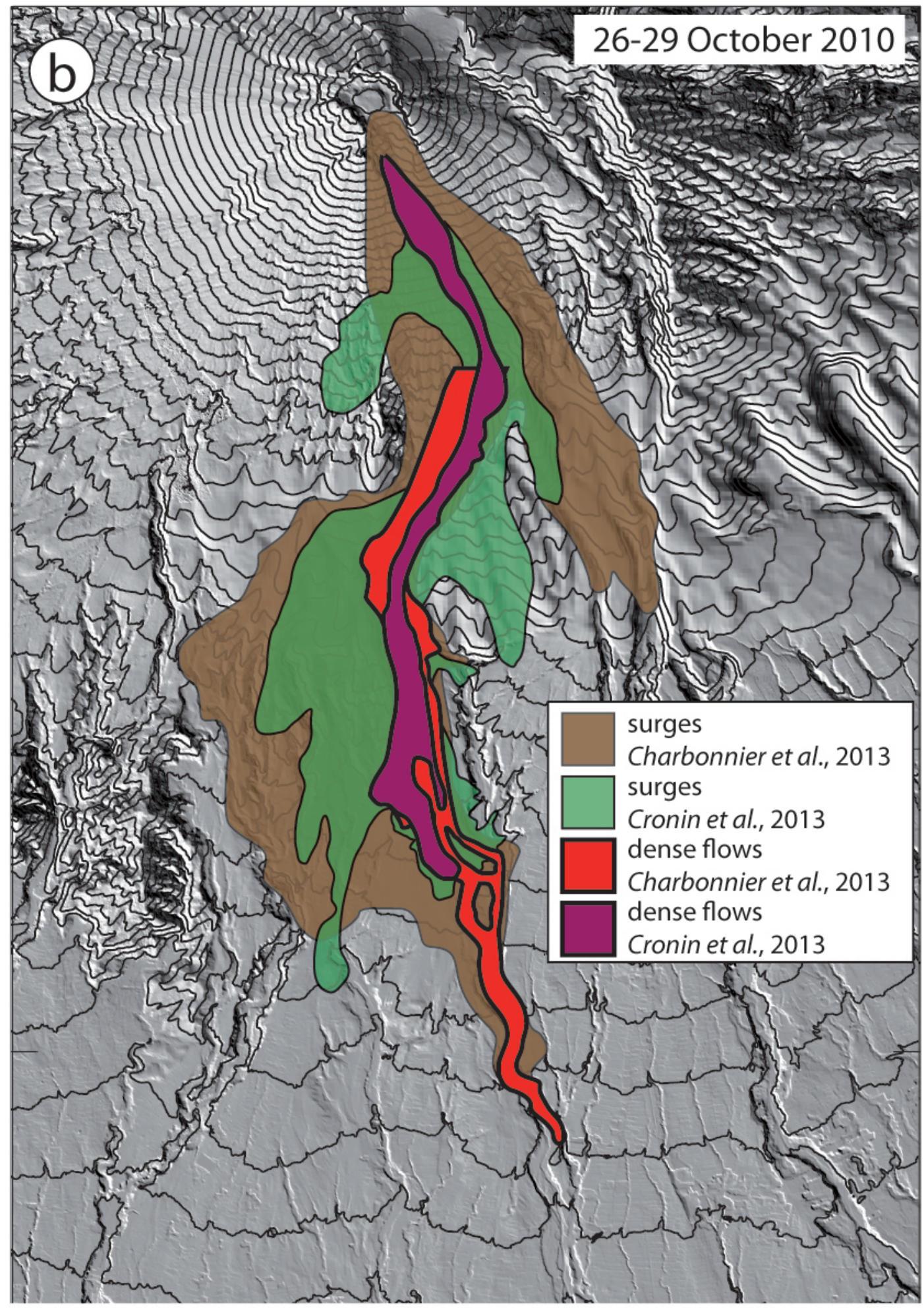

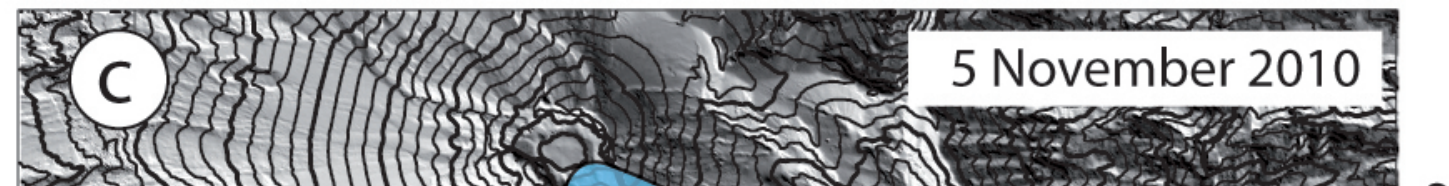

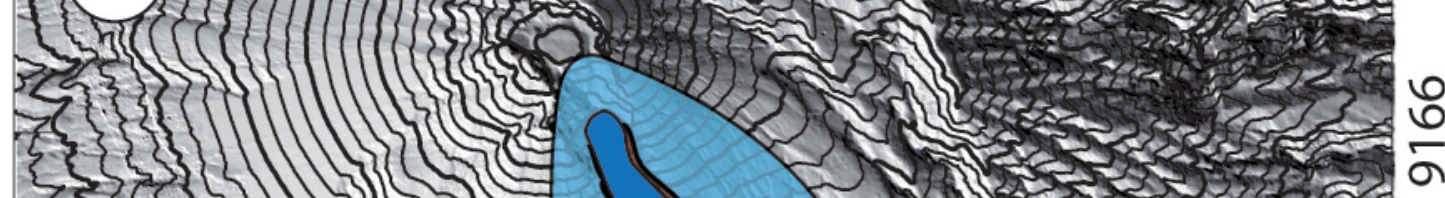
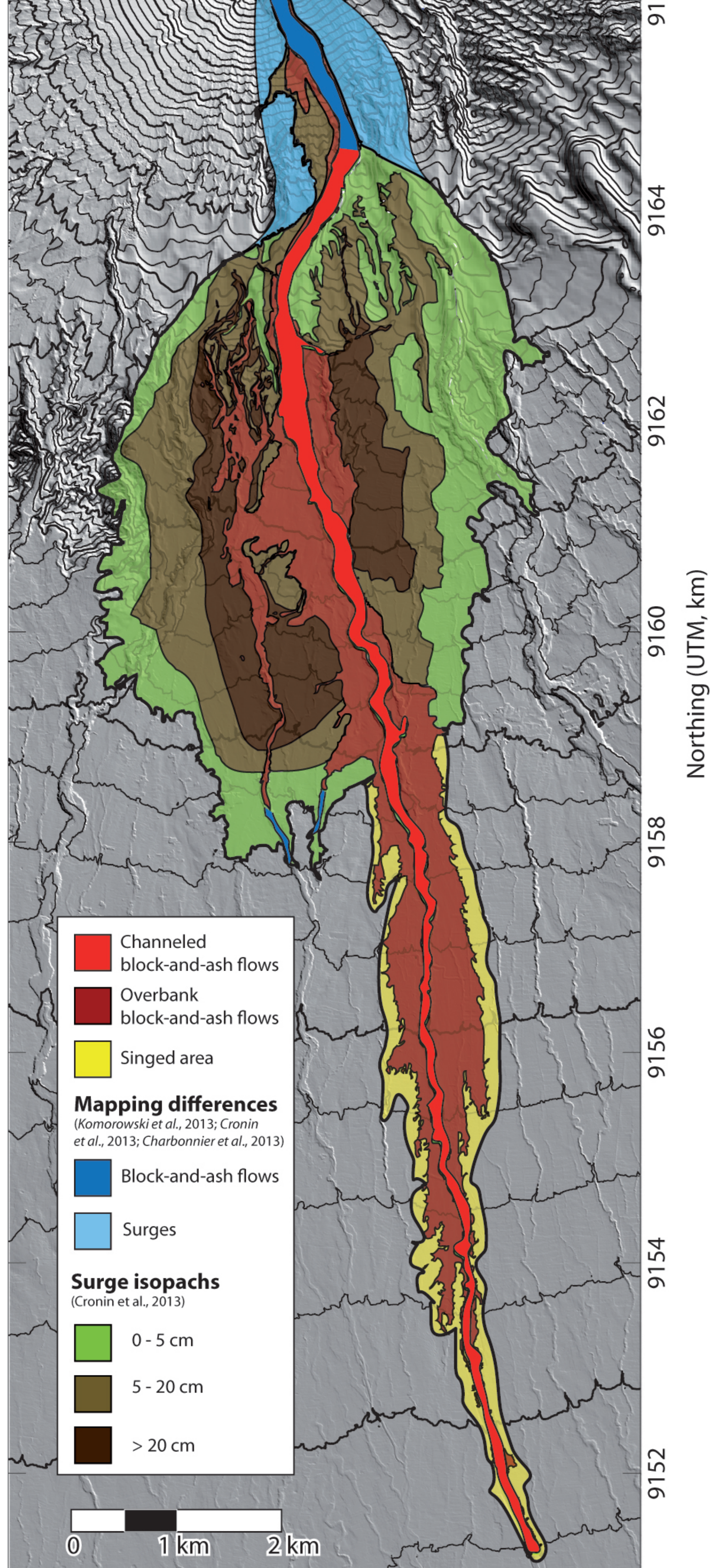

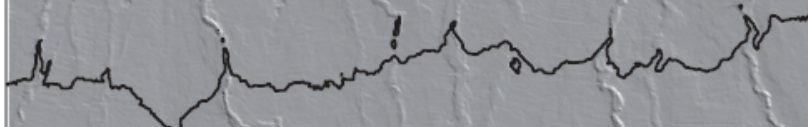



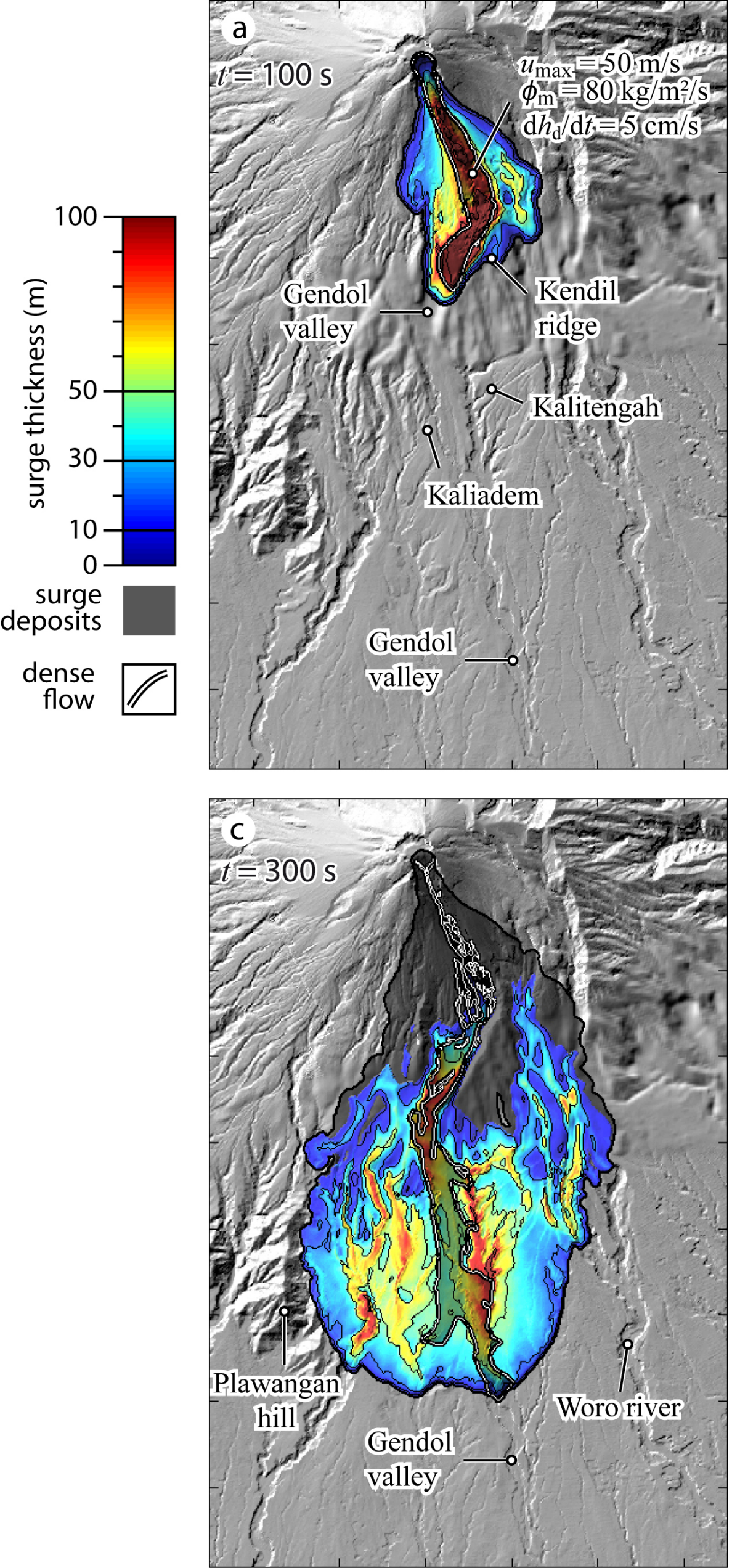
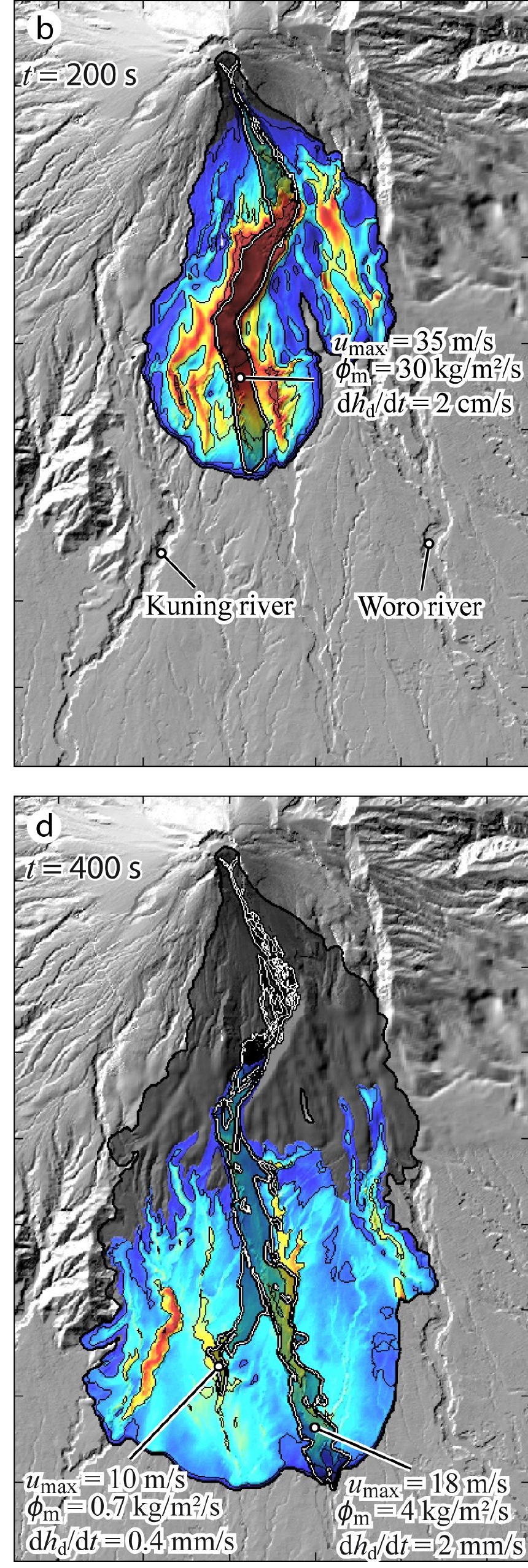


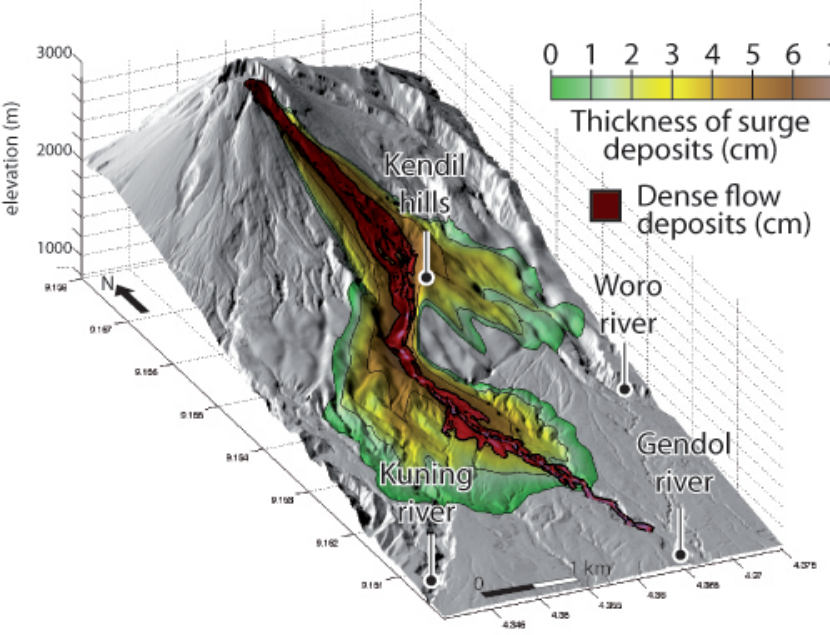


Table 1: parameters used in the model are known, estimated or calculated

Known or estimated from the field

\begin{tabular}{llc|llc}
$g$ & gravity $\left(\mathrm{m} \mathrm{s}^{-2}\right)$ & 9.78 & $d$ & particle diameter $(\mathrm{mm})$ & 0.25 \\
$\rho_{\mathrm{a}}$ & atm. density $\left(\mathrm{kg} \mathrm{m}^{-3}\right)$ & 1 & $z$ & topographic elevation $(\mathrm{m})$ & DEM \\
$\rho_{\mathrm{g}}$ & gas surge density $\left(\mathrm{kg} \mathrm{m}^{-3}\right)$ & 0.64 & $d_{\mathrm{s}}$ & source diameter $(\mathrm{m})$ & 200 \\
$\rho_{\mathrm{p}}$ & particle density $\left(\mathrm{kg} \mathrm{m}^{-3}\right)$ & 2400 & $t_{\mathrm{s}}$ & source duration (s) & 150 \\
$\rho_{\mathrm{d}}$ & dense flow density $\left(\mathrm{kg} \mathrm{m}^{-3}\right)$ & 1600 & & &
\end{tabular}

$\begin{array}{lcc} & \text { Simulation } & \text { Simulation } \\ & 26 \text { Oct. } & 5 \text { Nov. } \\ \quad \Rightarrow \quad \text { total volume }\left(\mathrm{m}^{3}\right) & 2 \times 10^{6} & 7 \times 10^{6} \\ \Rightarrow \text { volume rate }\left(\mathrm{m}^{3} \mathrm{~s}^{-1}\right) & 13.3 \times 10^{3} & 46.6 \times 10^{3}\end{array}$

Estimated by trials and errors

\begin{tabular}{llccc}
\hline & & $\begin{array}{c}\text { Simulation } \\
26 \text { Oct. }\end{array}$ & $\begin{array}{c}\text { Simulation } \\
5 \text { Nov. }\end{array}$ & $\begin{array}{c}\text { Range } \\
\text { explored }\end{array}$ \\
$a_{1}$ & $\mathrm{u}^{2}$ coefficient for the flow & 0.01 & 0.01 & $0-1$ \\
$a_{2}$ & turbulent coefficient of the surge & 0.05 & 0.3 & $0-1$ \\
$a_{3}$ & surge production coefficient & $7 \times 10^{-4}$ & $6.6 \times 10^{-4}$ & $0-10^{-2}$ \\
$C_{\mathrm{d}}$ & drag coefficient for particle settling & 32 & 25 & $0-100$ \\
$T_{0}$ & yield strength of the flow $(\mathrm{Pa})$ & 5000 & 2500 & $0-2 \times 10^{4}$ \\
$\rho_{\mathrm{m}}$ & mixture density $\left(\mathrm{kg} \mathrm{m}^{-3}\right)$ & 3 & 8 & $0-100$ \\
& & & \\
Calculated by the model & & & \\
\hline
\end{tabular}

$\begin{array}{ll}\mathbf{T}=\left(T_{x}, T_{y}\right) & \text { retarding stress of the flow } \\ \mathbf{R}=\left(R_{x}, R_{y}\right) & \text { retarding stress of the surge } \\ \phi_{\mathrm{m}} & \text { mass flux flow } \Rightarrow \text { surge } \\ \phi_{\mathrm{s}} & \text { mass flux surge } \Rightarrow \text { flow } \\ W_{\text {sed }} & \text { particle settling velocity } \\ P_{\text {dyn }} & \text { dynamic pressure }\end{array}$

$\begin{array}{ll}\mathbf{u}=\left(u_{x}, u_{y}\right) & \text { flow velocity } \\ \mathbf{v}=\left(v_{x}, v_{y}\right) & \text { surge velocity } \\ h & \text { flow thickness } \\ h_{\mathrm{s}} & \text { surge thickness } \\ \rho_{\mathrm{s}} & \text { surge density } \\ t & \text { time }\end{array}$


Table 2

\begin{tabular}{|c|c|c|c|c|c|c|}
\hline \begin{tabular}{l|l|l}
$<25 \%$ & $25 \%-50 \%$ & $>50 \%$
\end{tabular} & & Area S & Volume & Runout & Width & Area SF \\
\hline & & $\mathrm{km}^{2}$ & $\times 10^{6} \mathrm{~m}^{3}$ & $\mathrm{~km}$ & $\mathrm{~km}$ & $\mathrm{~km}^{2}$ \\
\hline Reference model & $\begin{array}{c}\text { values in } \\
\text { Tab. } 1\end{array}$ & $100 \%$ & $100 \%$ & $100 \%$ & $100 \%$ & $100 \%$ \\
\hline \multirow{2}{*}{ Particle diameter } & $d_{\mathrm{p}} / 2$ & $+19,96 \%$ & $+5,32 \%$ & $+13,71 \%$ & $+16,45 \%$ & $-53,49 \%$ \\
\hline & $d_{p} \times 2$ & $-17,45 \%$ & $-5,32 \%$ & $-11,04 \%$ & $-13,11 \%$ & $+93,02 \%$ \\
\hline \multirow{2}{*}{ Mixing density } & $\rho_{\mathrm{m}} / 2$ & $+24,38 \%$ & $-7,45 \%$ & $+1,65 \%$ & $+22,37 \%$ & $-65,12 \%$ \\
\hline & $\rho_{\mathrm{m}} \times 2$ & $-25,75 \%$ & $-5,85 \%$ & $-5,96 \%$ & $-14,40 \%$ & $+155,81 \%$ \\
\hline \multirow{2}{*}{ Surge formation } & $a_{3} / 2$ & $-34,38 \%$ & $-53,72 \%$ & $-12,94 \%$ & $-27,51 \%$ & $-62,79 \%$ \\
\hline & $a_{3} \times 2$ & $+36,37 \%$ & $+77,66 \%$ & $+10,66 \%$ & $+29,56 \%$ & $+83,72 \%$ \\
\hline \multirow{2}{*}{$u^{2}$-stress of the flow } & $a_{2} / 2$ & $+34,08 \%$ & $+69,68 \%$ & $+11,93 \%$ & $+29,05 \%$ & $+69,77 \%$ \\
\hline & $a_{2} \times 2$ & $-33,49 \%$ & $-53,19 \%$ & $-12,69 \%$ & $-26,99 \%$ & $-60,47 \%$ \\
\hline \multirow{2}{*}{ Duration of the collapse } & $t / 2$ & $+12,73 \%$ & $+4,79 \%$ & $+3,05 \%$ & $+12,60 \%$ & $-46,51 \%$ \\
\hline & $t \times 2$ & $-28,96 \%$ & $-6,38 \%$ & $-10,03 \%$ & $-17,99 \%$ & $+190,70 \%$ \\
\hline Flow volume & $V / 2$ & $-47,36 \%$ & $-56,91 \%$ & $-15,10 \%$ & $-35,22 \%$ & $-72,09 \%$ \\
\hline Gas density & $\rho_{\mathrm{g}}=\rho_{\mathrm{atm}}$ & $+40,61 \%$ & $+1,06 \%$ & $+18,15 \%$ & $+33,42 \%$ & $-37,21 \%$ \\
\hline
\end{tabular}


Journal of Geophysical Research - Solid Earth

Supporting Information for

Simulation of block-and-ash flows and ash-cloud surges of the 2010 eruption of Merapi volcano with a two-layer model.

Karim Kelfoun', Valentin Gueugneau', Jean-Christophe Komorowski ${ }^{2}$, Naning Aisyah'3 ${ }^{3}$ Noer

Cholik $^{3}$, Charley Merciecca ${ }^{1}$

1. Université Clermont Auvergne, CNRS, IRD, OPGC, Laboratoire Magmas et Volcans, F- 63000 ClermontFerrand, France

2. IPGP (Institut de Physique du Globe de Paris, Sorbonne Paris Cité, Université Paris Diderot, UMR 7154 CNRS), 1, rue Jussieu, 75238 Paris cedex 05, France.

3. BPPTKG (Balai Penyelidikan dan Pengembangan Teknologi Kegunungapian), Jl. Cendana no. 15 Yogyakarta - 55166, Indonesia.

\section{Contents of this file}

Figures S2

Table S3

\section{Additional Supporting Information (Files uploaded separately)}

Captions for Movies S1.

\section{Introduction}

The supporting information presents:

(1) a movie of the simulation of Fig. 2 and 3 of the manuscript;

(2) Twelve figures of simulations that illustrate the sensitivity of the model to the input parameters and a table summarizing the simulation characteristics.

Movie S1. Movie of the simulation of Fig. 2 and 3. Emplacement of the dense and the dilute currents for the 5 November 2010 eruption of Merapi volcano. Time is sped up: one second in the video for $50 \mathrm{~s}$ in reality.
$d_{\mathrm{p}} / 2$
$d_{\mathrm{p}} \times 2$
$\rho_{\mathrm{m}} / 2$
$\rho_{\mathrm{m}} \times 2$ 

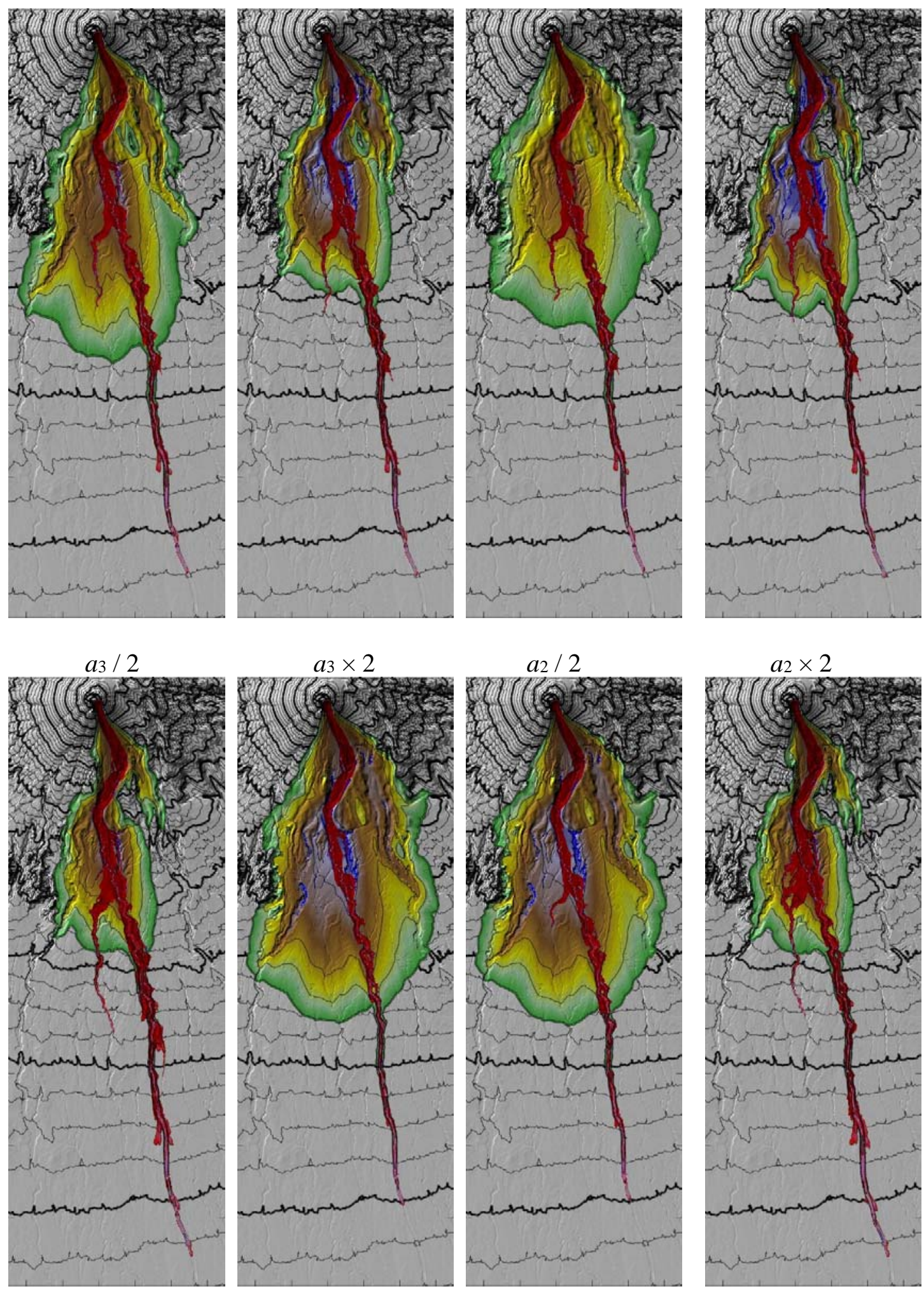

$t / 2$

$t \times 2$

V/2

$\rho_{\mathrm{g}}=\rho_{\mathrm{atm}}$ 

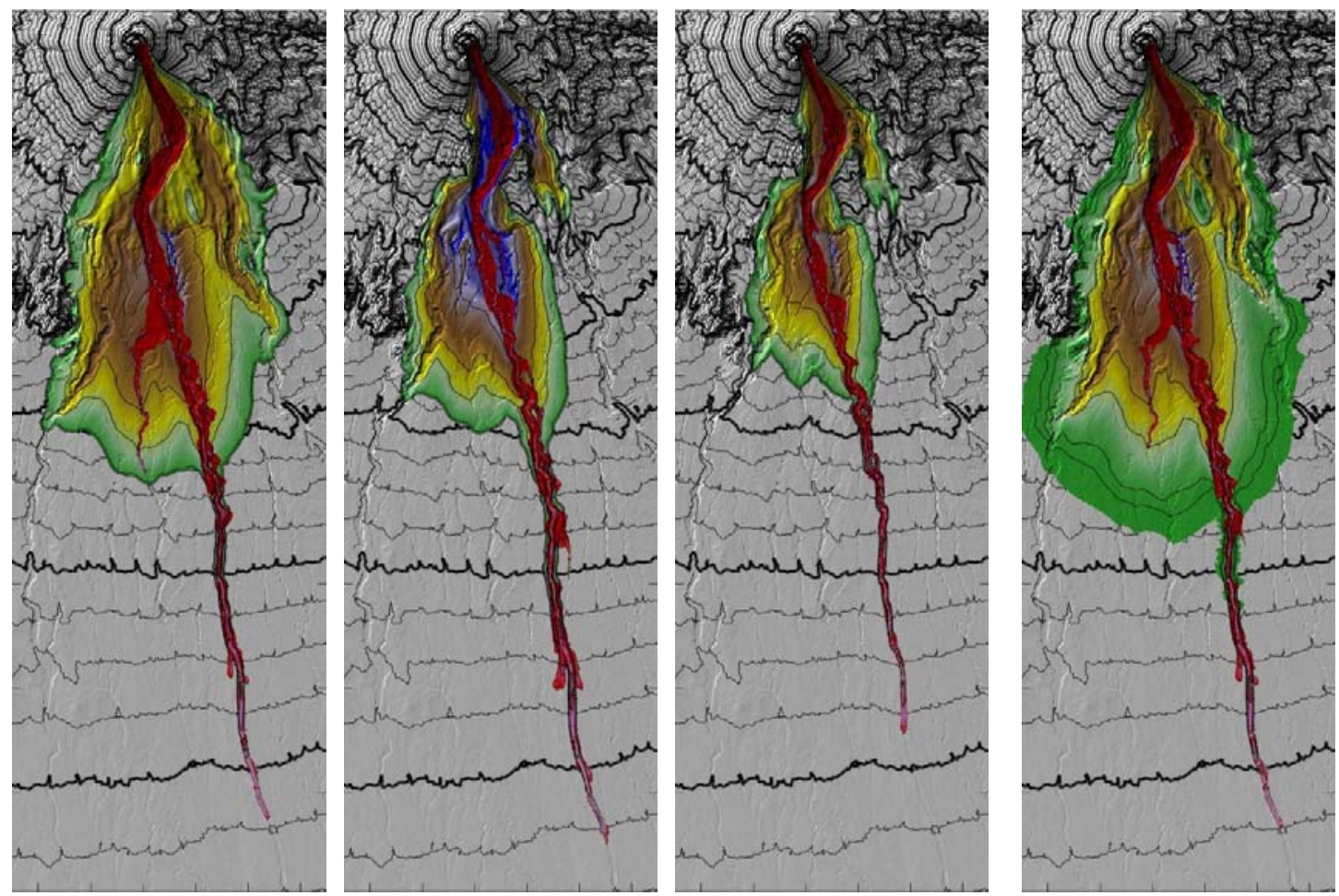

Figure S2. Those figures show the sensitivity to the parameters. Each title of figures refers to a line in the tables (Tab. 2 of the article and Tab. S3).

\begin{tabular}{|c|c|c|c|c|c|c|}
\cline { 3 - 7 } \multicolumn{2}{c|}{} & Area & Volume & Runout & Width & Area SF \\
\cline { 3 - 7 } \multicolumn{2}{c|}{} & $\mathrm{km}^{2}$ & $\mathrm{Mm}^{3}$ & $\mathrm{~km}$ & $\mathrm{~km}$ & $\mathrm{~km}^{2}$ \\
\hline $\begin{array}{c}\text { Reference } \\
\text { model }\end{array}$ & $\begin{array}{c}\text { values in } \\
\text { Tab. } 1\end{array}$ & 27.11 & 1.88 & 7.88 & 3.89 & 0.43 \\
\hline \multirow{2}{*}{$\begin{array}{c}\text { Particle } \\
\text { diameter }\end{array}$} & $d_{\mathrm{p}} / 2$ & 32.52 & 1.98 & 8.96 & 4.53 & 0.20 \\
\cline { 2 - 7 } & $d_{\mathrm{p}} \times 2$ & 22.38 & 1.78 & 7.01 & 3.38 & 0.83 \\
\hline \multirow{2}{*}{$\begin{array}{c}\text { Mixing } \\
\text { density }\end{array}$} & $\rho_{\mathrm{m}} / 2$ & 33.72 & 1.74 & 8.01 & 4.76 & 0.15 \\
\cline { 2 - 7 } & $\rho_{\mathrm{m}} \times 2$ & 20.13 & 1.77 & 7.41 & 3.33 & 1.10 \\
\hline \multirow{2}{*}{$\begin{array}{c}\text { Surge } \\
\text { formation }\end{array}$} & $a_{3} / 2$ & 17.79 & 0.87 & 6.86 & 2.82 & 0.16 \\
\cline { 2 - 7 } & $a_{3} \times 2$ & 36.97 & 3.34 & 8.72 & 5.04 & 0.79 \\
\hline \multirow{2}{*}{$\begin{array}{c}\text { u'-stress of } \\
\text { the flow }\end{array}$} & $a_{2} / 2$ & 36.35 & 3.19 & 8.82 & 5.02 & 0.73 \\
\cline { 2 - 7 } & $a_{2} \times 2$ & 18.03 & 0.88 & 6.88 & 2.84 & 0.17 \\
\hline $\begin{array}{c}\text { Duration of } \\
\text { the collapse }\end{array}$ & $t / 2$ & 30.56 & 1.97 & 8.12 & 4.38 & 0.23 \\
\cline { 2 - 7 } & $t \times 2$ & 19.26 & 1.76 & 7.09 & 3.19 & 1.25 \\
\hline Flow volume & $\mathrm{V} / 2$ & 14.27 & 0.81 & 6.69 & 2.52 & 0.12 \\
\hline Gas density & $\rho_{\mathrm{g}}=\rho_{\mathrm{atm}}$ & 38.12 & 1.90 & 9.31 & 5.19 & 0.27 \\
\hline
\end{tabular}


Table S3: sensitivity of the simulations to the input parameters variations. In the article, the difference is shown in percent while the absolute values are given here. Area $=$ total area covered by deposits $\left(\mathrm{km}^{2}\right)=$ area covered by the surge (e.g. $22.14 \mathrm{~km}^{2}$ for the reference model) + area covered by the flow $\left(\sim 5 \mathrm{~km}^{2}\right.$ for the reference model). Volume $=$ volume of surge deposits $\left(\times 10^{6} \mathrm{~m}^{3}\right)$, Runout $=$ maximal distance reached by the surge $(\mathrm{km})$, Width $=$ maximal surge width $\left(\mathrm{km}, \mathrm{E}-\mathrm{W}\right.$ direction), Area SF = area affected by secondary flows $\left(\mathrm{km}^{2}\right)$. The area covered by the surge-derived flow is very sensitive to all parameter changes. The volume of the surge deposit and the area covered by the surge are mostly sensitive to the parameters that control its genesis: $V, a_{2}$ and $a_{3}$. 